\title{
The Nogo Receptor Ligand LGl1 Regulates Synapse Number and Synaptic Activity in Hippocampal and Cortical Neurons
}

\author{
Rhalena A. Thomas, ${ }^{1}$ D Julien Gibon, ${ }^{2}$ Carol X. Q. Chen, ${ }^{1}$ Sabrina Chierzi, ${ }^{3}$ Vincent G. Soubannier, \\ Stephanie Baulac, ${ }^{4}$ Philippe Séguéla, ${ }^{1}$ Keith Murai, ${ }^{3}$ and Philip A. Barker ${ }^{1,2}$
}

DOI:http://dx.doi.org/10.1523/ENEURO.0185-18.2018

\begin{abstract}
${ }^{1}$ Department of Neurology and Neurosurgery, Montreal Neurological Institute, McGill University, Montreal, Quebec H3A 2B4, Canada, '2Department of Biology, University of British Columbia, Kelowna, British Columbia V1V 1V7, Canada, ${ }^{3}$ Department of Neurology and Neurosurgery, Centre for Research in Neuroscience, The Research Institute of the McGill University Health Centre, Montreal General Hospital, Montreal, Quebec, H3H2R9, Canada, ${ }^{4} U$ niversité Pierre-et-Marie-Curie Université Paris 06, Sorbonne Universités, Paris, 75005, France; Institut National de la Santé et de la Recherche Médicale, Unité 1127, Paris, 75006, France; Centre National de la Recherche Scientifique, Unité Mixte de Recherche 7225, Paris, France; Institut du Cerveau et de la Moelle Épinière), Paris, 75006, France; Groupe Hospitalier Pitié-Salpêtrière, Paris, 75013, France
\end{abstract}

\section{Visual Abstract}

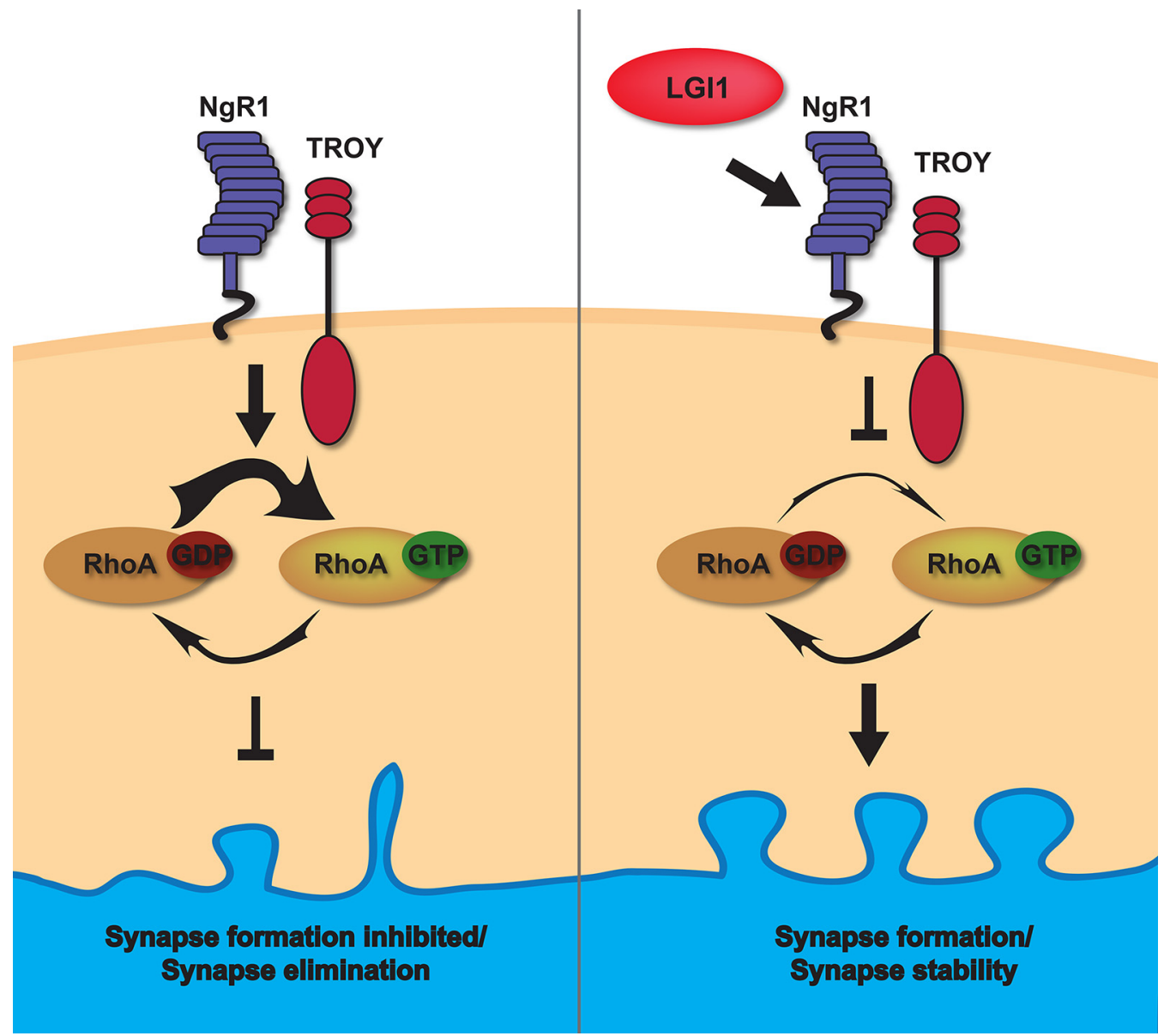




\section{Significance Statement}

Mutations in leucine-rich glioma-inactivated protein 1 (LGI1) causes autosomal dominant lateral temporal lobe epilepsy in humans. In the present study, we used a combination of cellular imaging, electrophysiology, protein analysis, and cell biology assays to show that LGI1 promotes synapse formation and maturation. LGI1 deletion in mice results in fewer synapses and causes synaptic activity defects. Mechanistically, LGI1 regulates RhoA signaling through a receptor complex containing Nogo receptor 1 (NgR1) and tumor necrosis factor receptor orphan Y (TROY). Our experiments provide evidence that NgR1 and LGl1 balance regulates RhoA activity during synapse formation and thus impacts on synapse maturation, number, and activity.

Leucine-rich glioma-inactivated protein 1 (LGI1) is a secreted neuronal protein and a Nogo receptor 1 (NgR1) ligand. Mutations in LGI1 in humans causes autosomal dominant lateral temporal lobe epilepsy and homozygous deletion of LGl1 in mice results in severe epileptic seizures that cause early postnatal death. NgR1 plays an important role in the development of CNS synapses and circuitry by limiting plasticity in the adult cortex via the activation of RhoA. These relationships and functions prompted us to examine the effect of LGl1 on synapse formation in vitro and in vivo. We report that application of LGl1 increases synaptic density in neuronal culture and that LGI1 null hippocampus has fewer dendritic mushroom spines than in wild-type (WT) littermates. Further, our electrophysiological investigations demonstrate that LGl1 null hippocampal neurons possess fewer and weaker synapses. RhoA activity is significantly increased in cortical cultures derived from LGl1 null mice and using a reconstituted system; we show directly that LGl1 antagonizes NgR1-tumor necrosis factor receptor orphan $Y$ (TROY) signaling. Our data suggests that LGl1 enhances synapse formation in cortical and hippocampal neurons by reducing $\mathrm{NgR} 1$ signaling.

Key words: epilepsy; leucine-rich glioma-inactivated gene 1; RhoA; synaptic activity; synaptic plasticity; TROY

\section{Introduction}

During development of the CNS, numerous synapses are produced and then pruned such that only synapses forming part of coordinated and active networks are retained, while the less active counterparts are lost. The structural and signaling components that stabilize active synapses and allow them to mature have been extensively studied and key elements that regulate this cascade have emerged (Craig et al., 2006; Gerrow and El-Husseini, 2006; Kano and Hashimoto, 2009). However, the processes that drive the elimination of non-active synapses remain uncertain.

Received May 10, 2018; accepted August 14, 2018; First published August 27, 2018.

The authors declare no competing financial interests.

Author contributions: R.A.T., P.S., K.M., and P.A.B. designed research; R.A.T., J.G., C.X.Q.C., and S.C. performed research; S.B. contributed unpublished reagents/analytic tools; R.A.T., J.G., S.C., V.G.S., and P.A.B. analyzed data; R.A.T., J.G., and P.A.B. wrote the paper.

This work was supported by Canadian Institute of Health Research (CIHR) Grants 37850 (to P.A.B.) and 130239 (to P.S.); the program "Investissements d'avenir" Grant ANR-10-IAIHU-06 (to S.B.); Fonds de Recherche du Québec Santé (FRQS) and McGill studentships (R.A.T.); and FRQS (J.G.).

Acknowledgements: We thank Robert Oda for help in writing the macros used for ImageJ analysis.

Correspondence should be addressed to Philip A. Barker, Department of Biology, University of British Columbia, Kelowna, British Columbia V1V 1V7, Canada, E-mail: philip.barker@ubc.ca.

DOI:http://dx.doi.org/10.1523/ENEURO.0185-18.2018

Copyright (C) 2018 Thomas et al.

This is an open-access article distributed under the terms of the Creative Commons Attribution 4.0 International license, which permits unrestricted use, distribution and reproduction in any medium provided that the original work is properly attributed.
Leucine-rich glioma-inactivated protein 1 (LGI1) is a secreted protein expressed in the CNS (Senechal et al., 2005). In humans, loss of LGl1 function can have major effects on circuit activity and function, with mutations in a single LGl1 allele causing an autosomal dominant form of lateral temporal lobe epilepsy (Kalachikov et al., 2002; Morante-Redolat et al., 2002). Indeed, deletion of LGI1 in mice results in spontaneous epileptic activity from postnatal day (P)10 and death from persistent seizures by P21 (Chabrol et al., 2010; Fukata et al., 2010; Yu et al., 2010). Recent studies have shown that auto-antibodies directed against LGI1 are responsible for a subset of cases of human autoimmune encephalitis characterized by memory disturbances, confusion, and seizures in adults (Irani et al., 2010; Lai et al., 2010; Ohkawa et al., 2013).

We previously showed that LGI1 is a ligand for the Nogo receptor 1 (NgR1), acting as a competitive antagonist that blocks binding of myelin-based NgR1 ligands and thereby preventing myelin-induced growth cone collapse (Thomas et al., 2010). LGl1 is also a ligand for ADAM22, ADAM23, and ADAM11 (Fukata et al., 2006, 2010; Sagane et al., 2008). ADAM22 interacts with PSD95 and may provide a platform for LGl1 to act at the synapse (Fukata et al., 2006; Lovero et al., 2015). Interestingly, ADAM22 also binds to NgR1 (Thomas et al., 2010), raising the possibility that $\mathrm{NgR} 1$ and various ADAM proteins may form a complex that allows LGl1 signals to be transduced at the synapse. NgR1 was initially identified as the receptor for Nogo66, for myelin-associated glycoprotein (MAG) and olygodendrocyte myelin glycoprotein (OMGP). When occupied by any of these ligands, NgR1 forms a signaling 
complex with either the p75 neurotrophin receptor (p75NTR) or the tumor necrosis factor receptor orphan $Y$ (TROY). These complexes then activate RhoA-dependent growth cone collapse and block neurite outgrowth (Fournier et al., 2001).

Intriguingly, $\mathrm{NgR} 1$ also plays important roles in the development of CNS synapses and circuitry. Early studies showed that $\mathrm{NgR}^{-/-}$mice have enhanced ocular dominance plasticity (McGee et al., 2005) and impairments in long-term depression (Lee et al., 2008). Mice overexpressing $\mathrm{NgR} 1$ have significant defects in long-term memory formation (Karlén et al., 2009). More recent work has demonstrated that NgR1-dependent RhoA activation plays a key role limiting synapse number during development (Wills et al., 2012) and that NgR1 plays a crucial role in limiting plasticity in the adult cortex in response to NogoA signaling (Akbik et al., 2013).

Both NgR1 and LGl1 are expressed in neurons throughout the brain and enriched in the hippocampus (Barrette et al., 2007; Head et al., 2007; Herranz-Pérez et al., 2010). LGI1 mRNA is found in neurons and the secreted LGI1 flag tagged protein is detected on both the cell soma and dendrite of hippocampal neurons in knock-in mice (Fukata et al., 2010). Electron microscopy analyses have revealed that LGI1 protein is present in presynaptic boutons (Boillot et al., 2016). NgR1 and its coreceptor TROY are also expressed in the dendrites of mouse hippocampal neurons (Wills et al., 2012). Here, we hypothesized that the interaction of LGI1 with $\mathrm{NgR} 1$ reduces RhoA signaling and thus promotes synapse formation and stabilization. In the present study, we report that exogenous application of LGl1 on primary culture of neurons increases synapse formation. In agreement with our hypothesis, we show that hippocampal neurons from $\mathrm{NgR}^{-/-}$mice form more synapses than their control neurons whereas neurons from $\mathrm{LGI} 1^{-/-}$form fewer synapse than their respective control in culture. In addition, an in vivo experiment reveals that $\mathrm{LGI}^{-/-}$mice have less mushroom-type spines than wild-type (WT) aged-matched animals. Consistent with our hypothesis, we then show that LGI1 restricts RhoA activation in primary neurons, and using a reconstituted cellular assay, we propose that LGI1 antagonizes NgR1:TROY-dependent RhoA activation.

\section{Materials and Methods}

\section{Animals}

All experimental procedures were approved by the McGill University Animal Care Committee and were in compliance with the guidelines of the Canadian Council on Animal Care. Animals were housed under standard conditions with a 12/12 h light/dark cycle and had free access to water and food. LGl1 mice were obtained from Dr. Stéphanie Baulac, previously reported by Chabrol et al. (2010). NgR1 mice were obtained from Dr. Sam David and Dr. Mark Tessier-Lavigne, previously described by Zheng et al. (2005). The sex of the embryos and pups used for primary cultures and hippocampal slices were not determined. Neither NgR1 or LGI1 deletion has been shown to alter sex distribution so we assume a 1:1 male: female ratio in experimental animals.

\section{Electrophysiology}

Slices of hippocampus were prepared from C57BL6 WT (RRID:IMSR_JAX:000664) and LGI1 ${ }^{-/-}$littermates mice (10 d old). The brains were rapidly removed and placed in ice-cold artificial CSF (ACSF; bubbled with $95 \% \mathrm{O}_{2} 5 \%$ $\mathrm{CO}_{2}$ ), which comprised: $124 \mathrm{mM} \mathrm{NaCl}, 2.5 \mathrm{mM} \mathrm{KCl}, 26$ $\mathrm{mM} \mathrm{NaHCO}_{3}, 1.25 \mathrm{mM} \mathrm{NaH}_{2} \mathrm{PO}_{4}, 2.5 \mathrm{mM} \mathrm{CaCl}_{2}, 1.3 \mathrm{mM}$ $\mathrm{MgCl}_{2}$, and $10 \mathrm{mM}$ D-glucose. Sagittal hippocampal slices $(300 \mu \mathrm{M})$ were prepared in ice-chilled, oxygenated ACSF using a vibratome VT1000S (Leica). Hippocampal slices were submerged in $\operatorname{ACSF}\left(23^{\circ} \mathrm{C}\right)$ for $2 \mathrm{~h}$ before transfer to the recording chamber $\left(30^{\circ} \mathrm{C}\right.$, flow rate $1 \mathrm{ml} /$ min). For whole-cell recordings, the pipette (4-10 $\mathrm{M} \Omega$ ) solution comprised: $120 \mathrm{mM} \mathrm{K-gluconate,} 10 \mathrm{mM}$ HEPES, $0.2 \mathrm{mM}$ EGTA, $20 \mathrm{mM} \mathrm{KCl}, 2 \mathrm{mM} \mathrm{MgCl}_{2}, 7 \mathrm{mM}$ diTrisPcreatine; $4 \mathrm{mM} \mathrm{Na} \mathrm{m}_{2} \mathrm{ATP}$, and $0.3 \mathrm{mM} \mathrm{NaGTP}$ ( $\mathrm{pH}$ adjusted to 7.3 with $\mathrm{KOH})$. CA1 neurons were voltage-clamped at -65 mV. For miniature EPSC (mEPSC) recording, $1 \mu \mathrm{M}$ TTX and $100 \mu \mathrm{M}$ picrotoxin (to block $\mathrm{GABA}_{\mathrm{A}} \mathrm{R}$ ) was added in the ACSF. In this study, all cells had a resting membrane potential ranging from -55 to $-75 \mathrm{mV}$. Cells with a resting membrane potential more positive than $-55 \mathrm{mV}$ were discarded. Analyses were made offline using the Mini analysis software. Neuronal excitability was assessed with a standard input/output curve obtained from an I-clamp step protocol (0-100 pA), in the presence of kinurenic acid and picrotoxin.

\section{Hippocampal and cortical cultures}

Hippocampal neurons and cortical neurons were dissociated and cultured as described by Kaech and Banker (2006). Cortical neurons were harvested from embryonic day $(E) 15-E 16$ mice and hippocampal neurons were taken from E16-E17 mice. Astrocytes were prepared from P0-P3 WT mice and grown in astrocyte media [DMEM 2 $\mathrm{mM}$ L-glutamine and $100 \mu \mathrm{g} / \mathrm{ml}$ penicillin/streptomycin (P/S) and 15\% BCS] and changed to neuronal growth media $48 \mathrm{~h}$ before coculturing with neurons. For quantification of synapses by immunofluorescence, hippocampal neurons were cultured on poly-L-lysine (PLL)-coated coverslips and inverted on astrocyte feeder layers for 15 and $18 \mathrm{~d}$ in vitro (DIV). Cultures were maintained in neural basal media supplemented with $2 \mathrm{mM}$ L-glutamine and $100 \mu \mathrm{g} / \mathrm{ml}$ P/S, $1 \%, 2 \%$ B27. One third of the media was removed and replaced with fresh media every 3-5 d.

\section{Exogenous LGI1}

Exogenous LGl1 was produced in 293E cells (RRID: CVCL_8869) and purified using a two-step tandem purification as previously described (Thomas et al., 2010). LGI1 protein was eluted in PBS and purity was assess by silver staining SDS page gels. The concentration of the purified protein was determined to be $16.75 \mu \mathrm{M}$. LGl1 was first added to complete neural basal growth media at $750 \mathrm{nM}$ concentration and for control treatment an equal volume of PBS was added. Treatments were added as a one third media change for a final LGl1 concentration of $250 \mathrm{nM}$. 


\section{Synapse quantification: immunostaining, image analysis, and quantification}

Dissociated neurons grown on coverslips for 15 and 18 DIV were fixed in 4\% PFA and 4\% sucrose in PBS for 30 min, washed once in PBS, then briefly permeablized in methanol. After 30 min of blocking (PBS, 2.5\% BSA and $2.5 \%$ goat serum), neurons were triple labeled with mouse anti-PSD95, 1:200 (Thermo Scientific, MA1-045, RRID: $\left.A B \_325399\right)$, rabbit anti-synapsin1 (Syn1), 1:2000 (a gift from Peter McPherson, McGill University), and chicken anti-MAP2A, 1:2000 (EnCor CPCA-MAP2), for $2 \mathrm{~h}$ at room temperature. Images were obtained using a Zeiss $A x$ ioObserver Z1 inverted microscope using a $40 \times$ objective and $1388 \times 1040$-pixel resolution $(0.161 \mu \mathrm{m} /$ pixel). For each experiment, images were acquired as a z-stack with 19 optical sections (0.3- $\mu \mathrm{m}$ step size) followed by deconvolution (constrained iterative method). Image analysis was performed such that genotypes were blinded to the observer during analysis. Image analysis was done using NIH software ImageJ software (Fiji, RRID:SCR_002285), according to the following procedure: for every image, the threshold for each channel was defined as two standard deviations above the mean. A region of interest (ROI) corresponding to the cell body was drawn manually and excluded from further analyses in all channels. From these images, colocalization analysis was performed with the RG2B plugin and regions of double colocalization more than two pixels in size were defined as particles. To calculate synapse density, the number of particles was divided by the length of dendrites measured using a binary mask of MAP2 labeling followed by the skeletonize function (minus the cell body).

\section{Twiss filters}

For analysis of protein levels in neurite processes, dissociated cortical neurons were seeded at high density (5 $\times 10^{5}$ cells) on PLL-coated filter inserts with astrocytes growing below the filter insert and maintained. Half the media was changed every $5 \mathrm{~d}$ on both the filter top and well bottoms. The protocol was adapted from Unsain et al. (2014). The filter tops containing cell bodies were harvested separately from the filter bottoms containing only axons and dendrites by the following method: filters were removed from the astrocyte-containing dish and placed into an empty dish containing PBS. The PBS was removed and the cell bodies were harvested: first by adding $100 \mu \mathrm{l}$ of PBS to the filter top and using a cell scraper to remove cells. Cells were moved to an Eppendorf tube containing Laemmli sample buffer. Filter tops were then washed several times with PBS and wiped clean with a cotton tip to make sure all cell bodies were removed. The filter was then cut free, cut to the center, and made into a cone shape. The filter cone was then submerged in Laemmli sample buffer and boiled for $5 \mathrm{~min}$. The samples were subjected to a high-speed spin, then the filters were removed and discarded. Samples were analyzed by Western blotting for actin (Fisher ICN691001, RRID:AB_2335127), Tuj1 (Covance MMS-435P, RRID:AB_2313773), LGl1 (Santa Cruz SC9583, RRID:AB_2134990), NgR1 (R\&D Systems AF1440, RRID:AB_2183731), PSD95 (Thermo Scientific
MA1-045, RRID:AB_325399), and synaptophysin (Syn; Sigma SVP-38, RRID:AB_2315393).

\section{Western blotting}

Samples were boiled for $5 \mathrm{~min}$, subjected to SDSPAGE, and transferred onto nitrocellulose membranes. The membranes were incubated in TBS-Tween (TBST; 10 $\mathrm{mM}$ Tris ( $\mathrm{pH} 8.0), 150 \mathrm{mM} \mathrm{NaCl}$, and $2 \%$ Tween 20) supplemented with $5 \%(\mathrm{w} / \mathrm{v})$ dried skim milk powder for 1 $\mathrm{h}$ at room temperature and then incubated with primary antibody in blocking solution for overnight at $4^{\circ} \mathrm{C}$. The membranes were then washed in TBST and incubated with secondary antibody conjugated to horseradish peroxidase for $1 \mathrm{~h}$ at room temperature. After the incubation, the membranes were washed with TBST, and immunoreactive bands were detected using an enhanced chemiluminescence solution kit (PerkinElmer Life Sciences).

\section{Dil labeling of dendrites and spine analysis}

P10 mice were anesthetized and quickly perfused with $4 \mathrm{ml}$ of PBS followed by $10 \mathrm{ml}$ of $4 \%$ PFA in PBS solution. Mice where decapitated, brains were removed and further fixed for $10 \mathrm{~min}$ in 4\% PFA, then moved to cold PBS. Hippocampi were removed and the tissue chopper was used to section hippocampi into $100-\mu \mathrm{m}$ slices. Slices were labeled using 1,1'-dioctadecyl-3,3,3',3'-tetramethylindocarbocyanine perchlorate (Dil)-coated tungsten particles as described in Gan et al. (2000). Images were taken using a spinning disk microscope at $63 \times(0.3-\mu \mathrm{m}$ step size) of entire dendrite sections. Sections of apical dendrites were selected from the primary branch point between 25 and $40 \mu \mathrm{m}$ in length mean values were obtained from four to six slices, and the mean values per animal were considered an $N$. Analysis was performed on max projections of z-stacks and measured in ImageJ. Measurements of spine length (L), head width $(\mathrm{Hw})$, and neck width (Nw) were taken. Spine types were categorized as mushroom (ratio Hw:Nw > 1.5), stubby (ratio Hw:Nw $=0.5-1.5$ and $\mathrm{L}: \mathrm{Nw}<1.5$ ), and thin (ratio Hw:Nw $=0.5-1.5$ and $\mathrm{L}: \mathrm{Nw}>$ 1.5). Genotypes were blinded to the observer during labeling, imaging, and analyses.

\section{GST-rhotekin binding domain (RBD) pulldown assay to measure active RhoA}

To detect active GTP-bound RhoA in lysates, lysates were prepared from high density $(500,000$ cells per well on a six-well plate) cortical neuron cultures prepared as described above/below and grown for 15 DIV. Cells were washed in ice cold TBS $10 \mathrm{mM}$ Tris (pH 7.5) and $150 \mathrm{mM}$ $\mathrm{NaCl}$ ) and lysed in $\mathrm{Mg}^{2+}$ lysis buffer [25 mM HEPES (pH 7.5), $150 \mathrm{mM} \mathrm{NaCl}, 1 \% \mathrm{NP}-40,10 \mathrm{mM} \mathrm{MgCl}, 1 \mathrm{mM}$ EDTA, $10 \%$ glycerol, with inhibitor mix (aprotinin $(0.5$ $\mu \mathrm{g} / \mathrm{ml})$, leupeptin $(0.5 \mu \mathrm{g} / \mathrm{ml})$, benzamidine $(100 \mu \mathrm{g} / \mathrm{ml})$, and PMSF $(20 \mu \mathrm{g} / \mathrm{ml})$ and phosphatase inhibitors $25 \mathrm{mM}$ $\mathrm{NaF}, 1 \mathrm{mM} \mathrm{NaOV}_{4}$. For a positive control, $20 \mu \mathrm{l}$ of $0.5 \mathrm{M}$ EDTA and $10 \mu \mathrm{l}$ of GTP $\gamma \mathrm{S}$ were added to one lysate and incubated at $30^{\circ} \mathrm{C}$ for $30 \mathrm{~min}$, and the reaction was quenched with $60 \mathrm{mM} \mathrm{MgC1} 1_{2}$. Lysates were incubated with GST-RBD beads for $1 \mathrm{~h}$ at $4^{\circ} \mathrm{C}$. GST-RBD-bound proteins were eluted in Lammeli sample buffer and analyzed by Western blotting. GST-RBD beads were pre- 
pared as originally described by Ren et al. (1999). Briefly, pGEX2T-RBD transformed Escherichia Coli, were stimulated with $1 \mathrm{mM} \mathrm{IPTG}$ at $30^{\circ} \mathrm{C}$. Pelleted cells were resuspended in $20 \mathrm{mM}$ HEPES (pH 7.5), $150 \mathrm{mM} \mathrm{NaCl}$, and 5 $\mathrm{mM} \mathrm{MgCl}$ with protease inhibitor mix. Cells were lysed by repeated freezing and thawing, followed by sonication and addition of Triton X-100, to a final concentration of $0.1 \%$. Lysates were incubated with GST beads for $1 \mathrm{~h}$, washed with lysis buffer, and eluted in Laemmli sample buffer, then visualize by Western blotting. Samples were analyzed by Western blotting for RhoA (Millipore, 05-778, RRID:AB_11213369).

\section{COS7 cell spreading/contraction assay}

COS7 cells (RRID:CVCL_0224) were maintained in DMEM with $10 \%$ bovine calf serum, $2 \mathrm{mM}$ L-glutamine, and $100 \mu \mathrm{g} / \mathrm{ml} \mathrm{P} / \mathrm{S}$. For transfection, 50,000 cells were seeded $1 \mathrm{~d}$ before transfection in 12-well plates. The following day, cells were transfected with a total of $2 \mu \mathrm{g}$ of DNA using lipofectamine 2000 (Invitrogen). DNA and lipofectamine were separately suspended in Opti-MEM media and then mixed. COS7 were washed in media without serum, and then the transection mix was added to the cells. Forty-eight hours after transfection, COS7 were trypsinized and reseeded onto glass coverslips $(12 \mathrm{~mm}$, Fisher Scientific), coated with laminin $(0.5 \mu \mathrm{g} / \mathrm{ml})$ for $2 \mathrm{~h}$, at a density of 5000 cells. Cells were fixed in $4 \%$ PFA in PBS for 30 min at room temperature $24 \mathrm{~h}$ after seeding and then washed with PBS and incubated with rhodamine-tagged WGA ( $5 \mu \mathrm{g} / \mathrm{ml})$ in PBS for $10 \mathrm{~min}$. Coverslips were washed with PBS $(3 \times 5 \mathrm{~min})$ and then quickly with water before mounting with anti-fading mounting media (Dako). Imaging was performed using a $40 \times$ objective on a Zeiss Axioskop fluorescent inverted microscope equipped with Xenon illumination, and images were captured using Zen software (Zeiss, RRID:SCR_014587). Cells too large to fit in one field of view and cells that appeared as bright rounded balls without any cytoplasm were excluded from analysis. The cell area of GFPexpressing cells was quantified using $\mathrm{NIH}$ ImageJ software (Fiji, RRID:SCR_002285) as follows. Images of rhodamine-tagged WGA membrane labeling were thresholded and made into mask and added as a ROI. ROls were added to the GFP image and ROls that were not GFP positive were deleted. The area of each cell (ROI) was determined using the measure tool.

\section{Experimental design and statistical analysis}

Statistical analysis was done using GraphPad Prism 6.0 (GraphPad Software, RRID:SCR_002798). Number of replicate and statistical tests are specified in figure legend for each experiment.

\section{Results}

\section{LGI1 regulates hippocampal neuron synapse number in vitro}

$\mathrm{NgR} 1$ activity suppresses synapse formation in the CNS and LGl1 acts as an NgR1 antagonist. Therefore, we hypothesized that during development, LGl1 functions to "suppress the suppressor," a prediction of this model is that application of exogenous LGI1 should favor synapse formation. To address this, WT hippocampal neurons were cultured in vitro for $13 \mathrm{~d}$ then subjected to either normal media or to media supplemented with purified LGl1 for $6 \mathrm{~d}$ and then fixed at 18 DIV (final LGl1 concentration was $250 \mathrm{nM}$ ). After treatment cells were fix and immunocytochemistry was used to detect Syn1 and PSD95, the pre- and postsynaptic markers used to quantify synapse number, as detailed in Materials and Methods. Interestingly, treatment with exogenous LGl1 caused a large increase in synaptic density, enhancing synapse number from a normalized baseline of 1.00 to 2.49 (Fig. $1 A-C)$. Thus, exogenous LGl1 potently promotes synapse formation on hippocampal neurons in vitro.

A key aspect of our model is that $\mathrm{NgR} 1$ activity reduces synapse number in hippocampal neurons, as reported previously (Wills et al., 2012). To confirm this, we analyzed synapse number in hippocampal neurons derived from $\mathrm{NgR}^{-/-}$mice or their WT littermates at two time points: 15 DIV approaching the peak of in vitro synapse formation and 18 DIV the point at which cultures are first considered mature. Figure $2 A-D$ shows that $\mathrm{NgR}^{-/-}$hippocampal neurons have significantly more synapses than their WT counterparts, both at 15 DIV (increased 52\%, normalized values increased to 1.523), and at 18 DIV (increased $47 \%$ normalized values increased to 1.468), agreeing with findings of Wills et al. (2012). Given this effect of NgR1, and given our previous findings showing that LGl1 normally acts to suppress NgR1 activity (Thomas et al., 2010), we predicted that loss of exogenous LGl1 would result in increased $\mathrm{NgR} 1$ activity that would in turn reduce synapse number. To address the latter point, we assessed synapse number in hippocampal neurons derived from $\mathrm{LGI}^{-1 /}$ mice or their WT littermates at two time points. Figure $3 A-D$ shows that the number of synapses was significantly decreased in $\mathrm{LGI}^{-/-}$neurons examined at 15 DIV (reduced 18\%, normalize values decreased from $1-0.82$ ) and at 18 DIV (reduced $33 \%$, normalized values decreased from 1 to 0.66 ). Thus, loss of exogenous NgR1 and loss of LGl1 produced qualitative results that are consistent with our model.

To gain insight into the role of NgR1 and LGl1 on the developmental progression of synapse formation in vitro, we developed a filter-based assay that allowed us to monitor the accumulation of synaptic marker proteins selectively in neurites undergoing synaptogenesis (Unsain et al., 2014). In this approach, primary hippocampal neurons were plated on the top of a filter insert and maintained in wells containing an astrocyte feeder layer (shown schematically in Fig. 4A). Over several days, neurites project from the cell body and a subset of these project to the bottom of the filter, where they eventually make contacts with neighboring neurites and form synapses. The cell bodies are too large to pass through the filter pores and are therefore retained on the filter top. Thus, by collecting material from the filter bottom, we can assess the selective accumulation of synaptic markers in the neurite compartment.

Figure $4 B$ shows the accumulation of several proteins on the top and bottom of the filters from WT neurons 
A

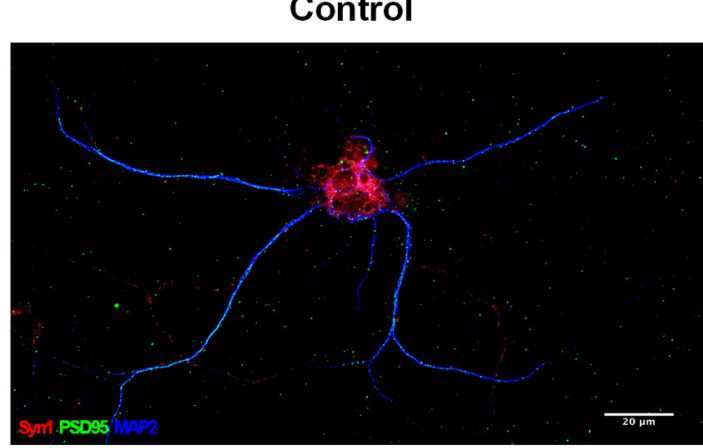

+ LGI1

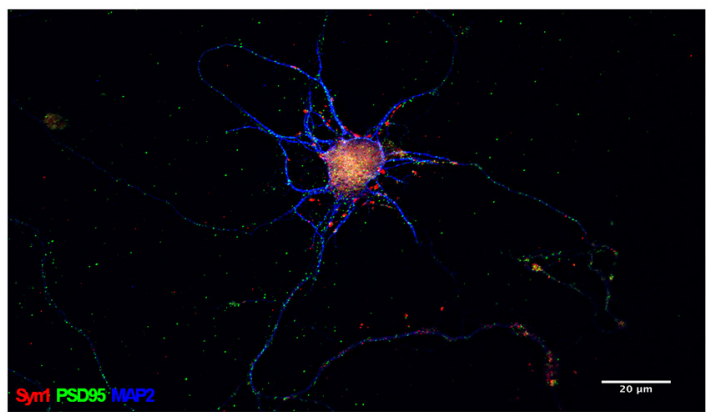

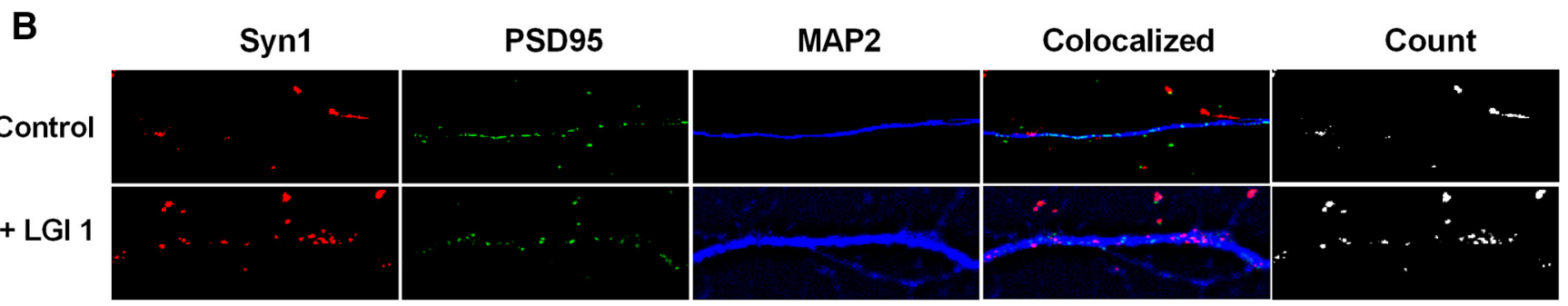

C

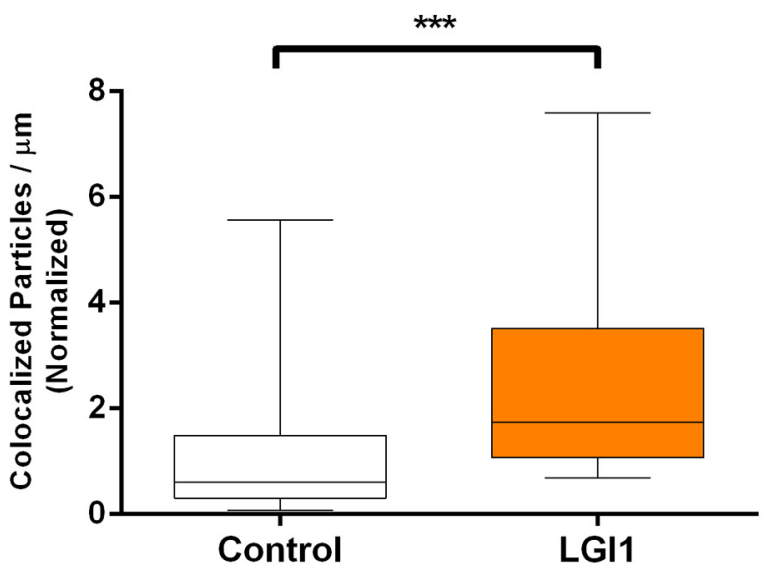

Figure 1. Exogenous application of LGl1 promotes synapse formation. $\boldsymbol{A}$, Representative images from 18 DIV cultures hippocampal neuron labeled with Syn1 (red), PSD95 (green), and MAP2 (blue) in the absence and presence of exogenous LGI1 (6 DIV treatment). $\boldsymbol{B}$, Magnification of sample images; the panel labeled "count" indicates colocalized particles of Syn1 and PSD95 considered to be synaptic puncta. $\boldsymbol{C}$, Quantification of synaptic density indicated by colocalized puncta per $\mu \mathrm{m}$ of MAP2-labeled dendrites excluding the cell bodies. Data are shown as box plots with whiskers from $1^{\text {st }}$ to 99th percentile. Differences were analyzed by unpaired $t$ tests, $* * * p=0.0007 ; N=34$ WT and 29 treatment neurons from three separate cultures (8-14 images were included for each condition in each experiment).

maintained 4, 8, 12, 15, and 18 DIV. Histone H3 was present only on the filter top, indicating that cell bodies are retained in this compartment (Fig. 4B, bottom lane). In the top compartment, levels of actin and tubulin levels remain relatively steady whereas levels of Syn and PSD95 become detectable and rise dramatically starting at 12 DIV (Fig. 4B). Levels of LGI1 and NgR1 also start to increase in the top compartment at 12 DIV, consistent with their playing a role in the regulation of synapse formation. In the bottom compartment, actin and tubulin become detectable at 8 DIV and increase until 12 DIV, likely reflecting the growth of neurites onto the bottom of the filter. Syn, PSD95, LGI1, and NgR1 are undetectable at 8 DIV but readily detectable at 12 DIV, after which they remain stable.

With these baselines established, we then examined the protein composition of $\mathrm{LGI}^{-/-}$and $\mathrm{NgR}^{-/-}$neurites projecting to the bottom cell-free compartment, relative to WT littermates in each instance. Figure $4 C, D$ shows PSD95 levels are sharply decreased $(p=3.69 e-05)$, and Syn levels modestly and not significantly decreased ( $p=$ 0.0807 ), in LGI1 ${ }^{-/-}$neurites examined at 12, 15 , or 18 DIV. In direct contrast, $\mathrm{NgR}^{-/-}$mice examined at 12, 15, and 18 DIV show a strong increase in PSD95 levels $(p=$ $0.00024)$, as well as a more modest and not significant, increase in Syn levels $(p=0.0978$; Fig. $4 E, F)$. Taken 

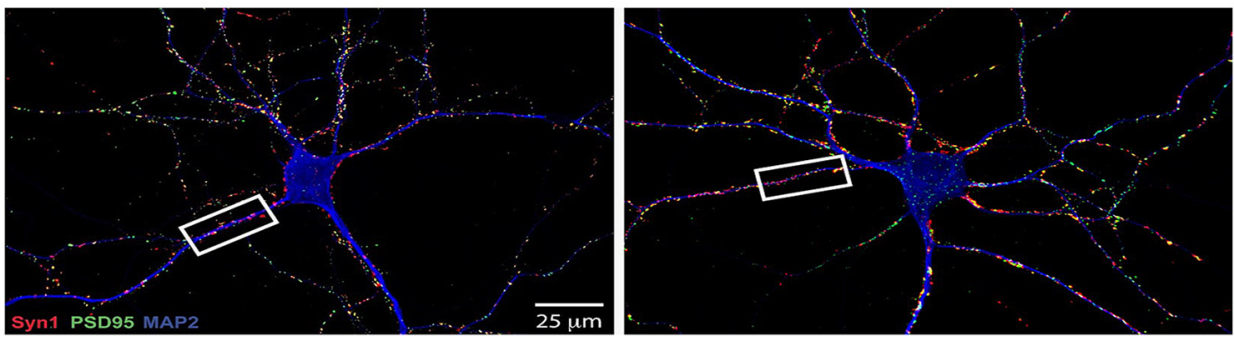

B

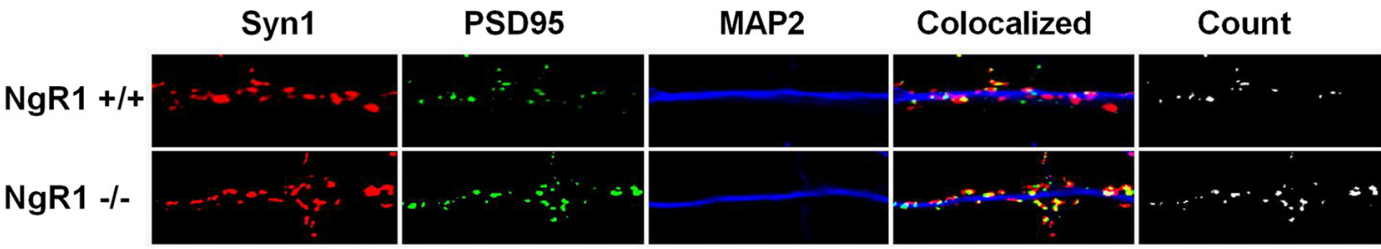

C

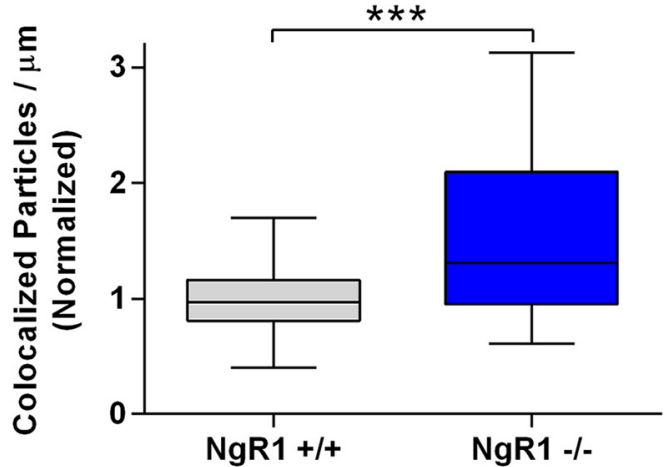

D

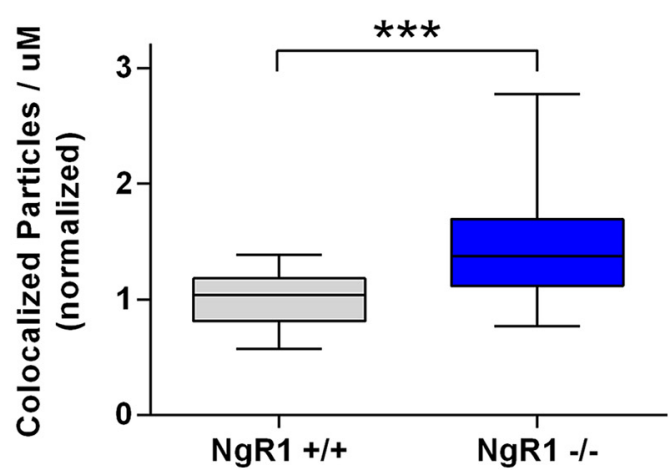

Figure 2. NgR1 regulates synapse number in dissociated hippocampal neurons. Analysis of synapse density from cultured hippocampal neurons grown on coverslips for 15 or 18 DIV. A, Representative images from 18 DIV cultures labeled with Syn1 (red), PSD95 (green), and MAP2 (blue), genotypes are indicated. $\boldsymbol{B}$, Magnification of sample images shown in the white box in $\boldsymbol{A}$ used for quantification. The panel labeled "count" indicates colocalized particles of Syn1 and PSD95 considered to be synaptic puncta. $\mathbf{C}$, Quantification of synaptic density indicated by colocalized puncta per $\mu \mathrm{m}$ of MAP2-labeled dendrites excluding the cell bodies for 15 DIV cultures. $\boldsymbol{D}$, Same as $\boldsymbol{C}$ but for 18 DIV cultures. Values in quantification were normalized to WT littermates within each culture. Data are shown as Box plots with whiskers from 1st to 99th percentile. $\mathrm{NgR}^{-/-}$neurons display significantly more synapses than $\mathrm{NgR} 1^{+/+}$littermates. For 15 DIV cultures, $\mathrm{NgR}^{+/+} n=29$ neurons and $\mathrm{NgR}^{-/-} n=28$ neurons from three cultures. For 18 DIV cultures, $\mathrm{NgR}^{+/+} n=25$ neurons and $\mathrm{NgR}^{-/-} n=31$ neurons from three separate cultures. Differences were analyzed by unpaired $t$ tests, $* * * p<0.001$.

together with other findings above, these results suggest that $\mathrm{NgR} 1$ suppresses synaptogenesis and that LGI1 antagonizes this effect.

By physically associating with transmembrane proteins, p75NTR or Troy, NgR1 forms the ligand-binding portion of a receptor complex that induces RhoA activity. Since LGI1 can function as a NgR1 antagonist, we predicted that loss of endogenous LGI1 would increase constitutive RhoA activation levels in primary central neurons. To address this, $\mathrm{LGI}^{-/-}$cortical neurons, and corresponding littermate WT neurons, were maintained in vitro for $15 \mathrm{~d}$ and then subjected to GST-rhotekin pulldown assays to assess active RhoA levels. Figure $5 A, B$ shows that levels of active RhoA are $71 \%$ higher in $\mathrm{LGl} 1^{-/-}$primary neurons than in their WT counterparts, consistent with the hypothesis that endogenous LGI1 suppresses constitutive NgR1-dependent RhoA activity in cortical neurons.p75NTR levels are very low in the hippocampus and the $\mathrm{NgR} 1$ signaling complex consists of NgR1 complexed with TROY (Wills et al., 2012). To determine whether LGl1 can alter signaling mediated by the NgR1-TROY complex, we developed a reconstituted cellular assay that would allow us to assess the role of individual components in the signaling cascade, in the absence of potential compensatory receptors and ligands. The approach is based on the RhoA-dependent contraction in cell size that occurs in COS7 cells and allows us to manipulate specific signaling components and assess their effects on RhoA activation, measuring cell area as a proxy for small GTPase activation (Zeinieh et al., 2015; Thomas et al., 2016). It is well established RhoA mediates cell contraction, by initiating actin cytoskeleton remodeling (for review, see Kaibuchi et al., 1999; Etienne-Manneville and Hall, 2002) and 

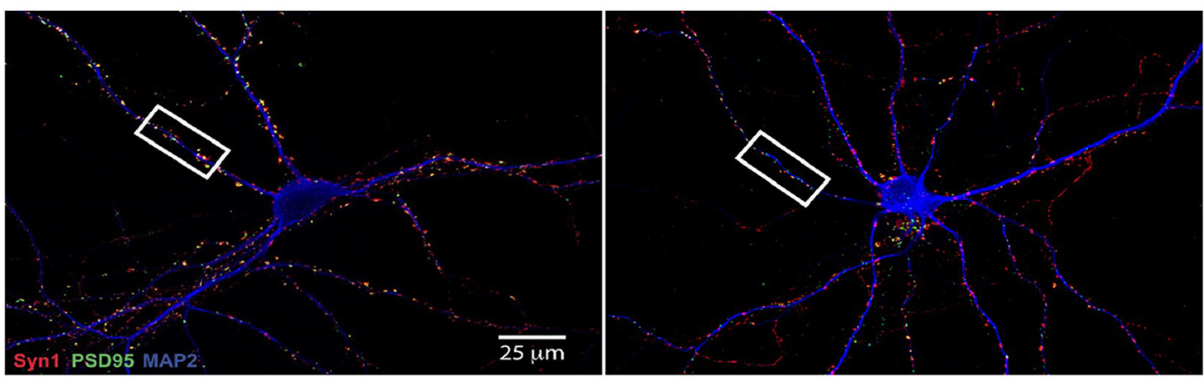

B
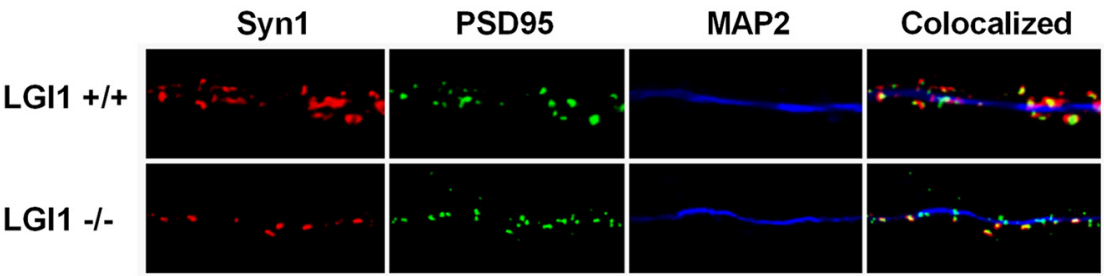

Count

C

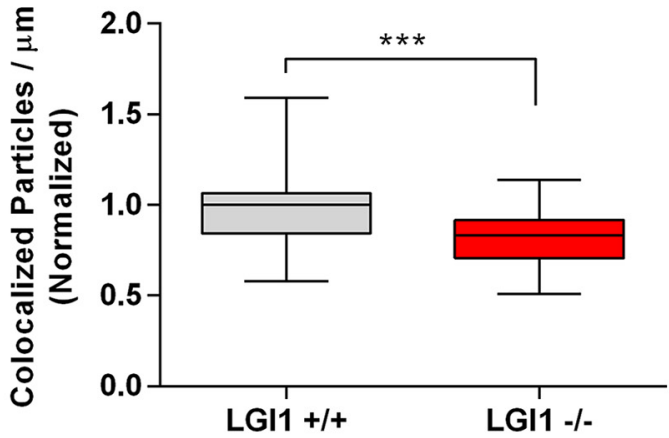

D

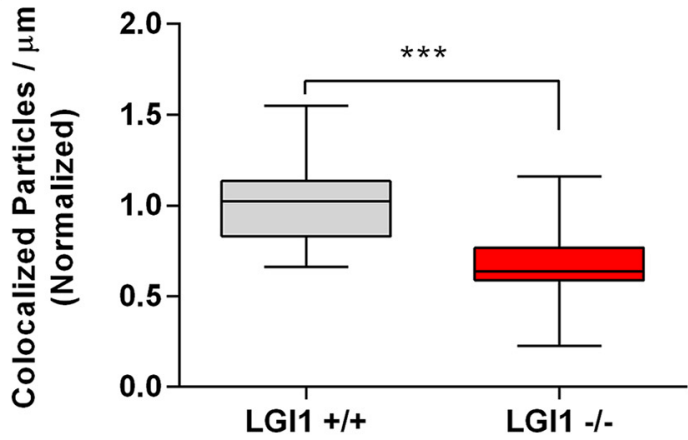

Figure 3. LGl1 regulates synapse number in dissociated hippocampal neurons. Analysis of synapse density from hippocampal neurons dissociated from E16 embryos grown on coverslips for 15 or 18 DIV. Panels $\boldsymbol{A}$, $\boldsymbol{B}$ show representative images from 18 DIV cultures labeled with Syn1 (red), PSD95 (green), and MAP2 (blue), genotypes are indicated. Sample images of LGI1 ${ }^{+/+}$and LGl1 ${ }^{-/}$ neurons used in analysis of synaptic density, quantified from the number of colocalized Syn1 and PSD95 puncta per $\mu \mathrm{m}$ of MAP2-labeled dendrites excluding the cell bodies. $\boldsymbol{B}$, Enlarged images from the box highlighted in $\boldsymbol{A}$. The far right panel indicated "count" shows the colocalized puncta representing the synapse. Values in quantification were normalized to WT littermates within each culture. Data are shown as box plots with whiskers from 1st to 99th percentile. LGl1 ${ }^{-/-}$neurons have significantly fewer synapses than $\mathrm{LGI} 1^{+/+}$littermates. C, Synapse density quantified from 15 DIV cultures. $\boldsymbol{D}$, Synapse density quantified from 18 DIV cultures. $\mathrm{LGI}^{+/+} n=40$ neurons from four cultures, $\mathrm{LGl}{ }^{-/-} n=40$ from four cultures; $* * * p<0.001$ (unpaired $t$ test).

that $\mathrm{NgR} 1$ together with a coreceptor activates RhoA signaling (Wong et al., 2002; Yamashita and Tohyama, 2003; Park et al., 2005; Shao et al., 2005; Wills et al., 2012). Figure $6 A, B$ shows that when expressed individually, neither LGl1, $\mathrm{NgR} 1$, or TROY had any effect on cell size. However, coexpression of NgR1 and TROY causes a highly significant cellular contraction, suggesting that they interact and activate $R$ hoA in $\operatorname{COS} 7$ cells. Figure $6 B$ shows that this RhoAdependent contraction was completely blocked when LGl1 was coexpressed with $\mathrm{NgR} 1$ and TROY, indicating that LGl1 is a potent antagonist of the NgR1-TROY complex.

\section{LGI1 deletion results in changes in spine morphology and synaptic function}

Our next series of studies examined the effects of LGl1 on synaptic morphology and function in vivo. In these studies, we had to balance the complications of assess- ing synapse structure and function in juvenile animals against the incipient seizures that are initiated in the perinatal period, at P11. We therefore chose $\mathrm{P} 10$ as the most appropriate age in which to carry out these studies.

To analyze dendritic spine morphology in vivo, we generated hippocampal slices from P10 LGl1 ${ }^{-/}$and littermate mice and used a biolistic approach to label well separated CA1 pyramidal neurons with Dil. Spine length, neck width and head width were measured on 25 - to $40-\mu \mathrm{m}$ sections of apical dendrites, just distal to the primary branch point, which allowed us to categorize spines as mushroom, stubby, or thin. Figure $7 A$ shows representative images of the segments used for analysis. The number of total spines showed a trend toward being reduced in $\mathrm{LGI}^{-1-}$ mice compared to WT neurons $(p=0.17$; Fig. $7 B)$. Interestingly, there was a significant reduction in the incidence of mushroom spines (Fig. 7C). We observed a 
A

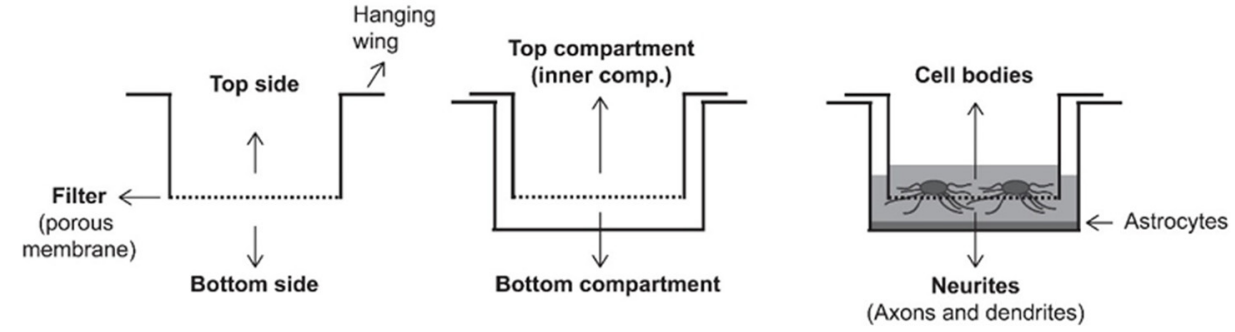

B
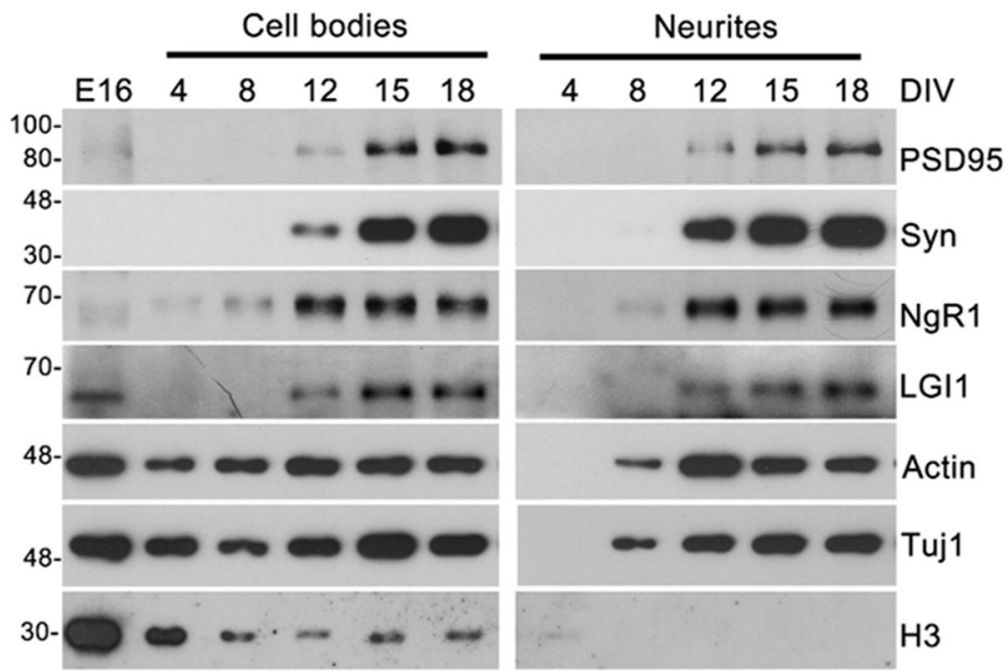

C
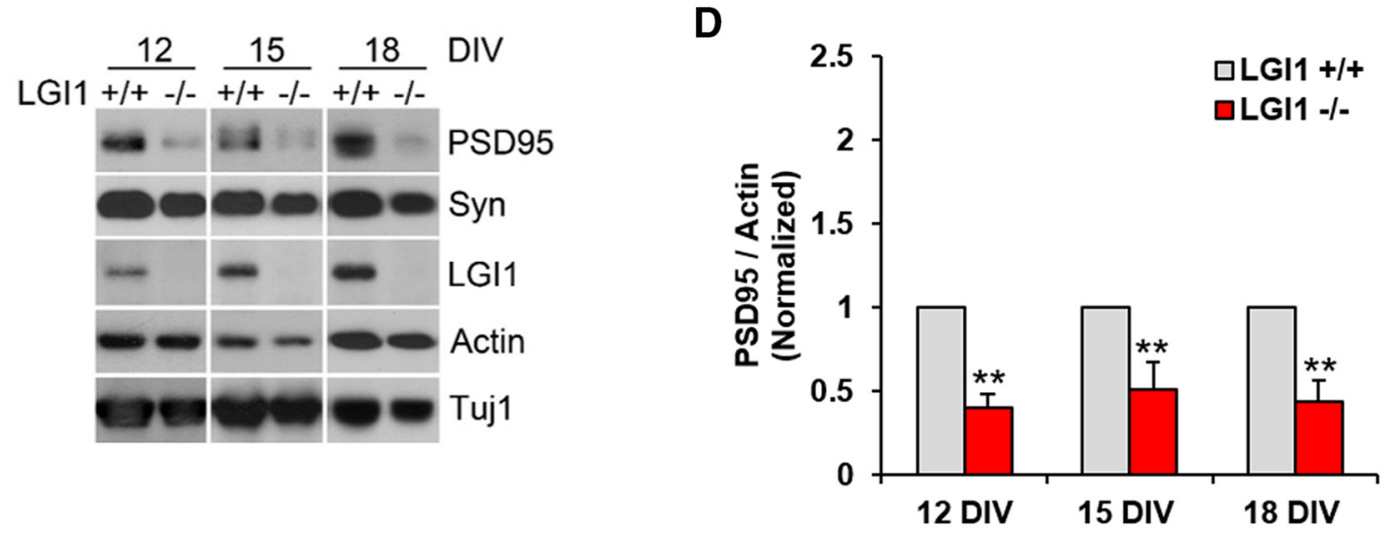

$\mathbf{E}$

$\mathbf{F}$
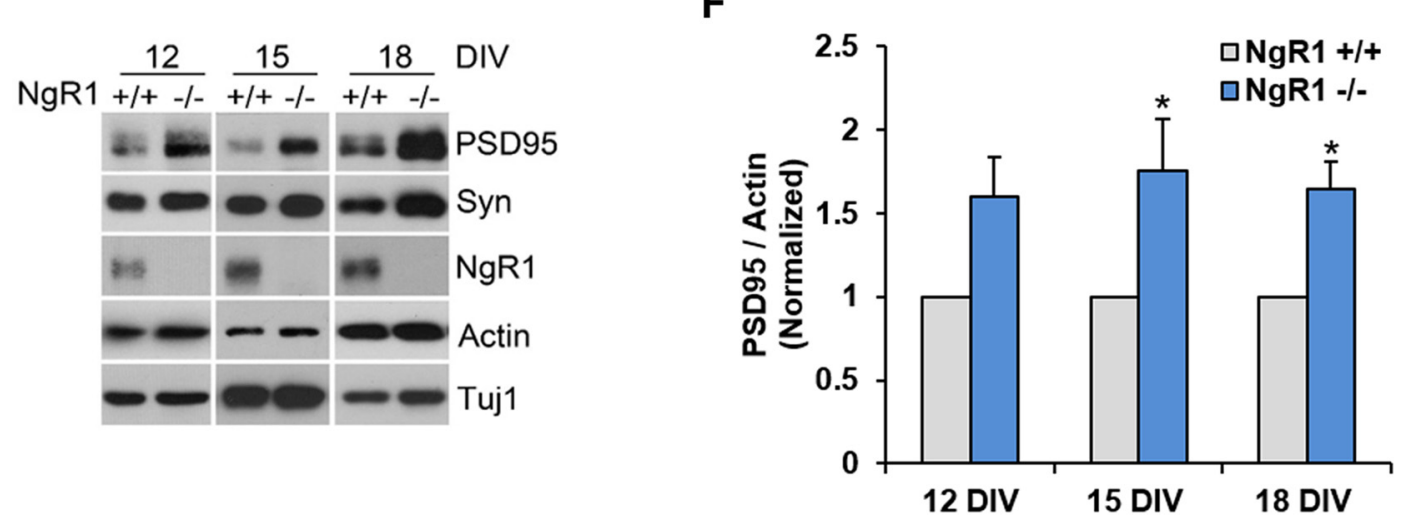

Figure 4. NgR1 and LGl1 regulate synaptic proteins in cortical neurons in vitro. $\boldsymbol{A}$, Twiss filter schematic showing culture system to coculture hippocampal neurons with astrocytes and separate neuronal processes from cell bodies. Hippocampal neurons seeded on filters with a pore size $1 \mu \mathrm{m}$ that cell bodies will not pass through. Axons and dendrites grow on the filter tops and extend down onto the filter bottom. Astrocytes are seeded on the bottom of the well to provide growth factors. B, Time course of lysates from 


\section{continued}

hippocampal neurons grown on filters suspended over an astrocyte feeder layer for the times indicated. The first lane in the left panel labeled E16 is a sample of hippocampal neurons lysed directly after dissociated before plating. Lysates from filter tops including cell bodies and processes are on the left. Lysates of the filter bottoms containing axons and dendrites but no cell bodies are on the right. Antibodies used to probe the lysates are indicated on the right. Histone-3 $(\mathrm{H} 3)$, a structural protein found in chromatin and present only in the nucleus is detected only in the cell body lysates. C. Lysates from filter bottoms containing axons and dendrite but not cell bodies from $\mathrm{LGl}^{+/+}$and $\mathrm{LGl} 1^{-/-}$littermates of cortical cultures grown for the indicated number of DIV. $\boldsymbol{D}$, Quantification of PSD95 levels relative to actin levels and normalized to WT controls in LGI1 samples at 12, 15 , and 18 DIV, $n=3$ separate experiments. $\boldsymbol{E}$, Western blottings of lysates from filter bottoms of $\mathrm{NgR}^{+/+}$and $\mathrm{NgR}^{-/-}$cortical cultures harvested at 12,15 , or 18 DIV synaptic markers, Syn and PSD95. Actin and Tuj1 are loading controls. F, Quantification of PSD95 relative to actin levels and normalized to WT controls in NgR1, $n=4$ separate experiments. Significant differences are indicated on the graphs analysis was performed by two-way ANOVA with Bonferroni post hoc tests, $* * p<0.01, * p<0.05$.

significant decrease in the proportion of mushroom spines, but the corresponding increase in other spine types was not significant (Fig. 7D). We also analyzed the spine length, spine stem width, and spine head width across all categories of spines and found that overall spine length was significantly decreased in $\mathrm{LGI}{ }^{-1-}$ mice compared to controls (Fig. 7E). Focusing specifically on mushroom-like spines, we found that LGI1 $1^{-1-}$ neurons displayed a significant decrease in spines length compared to WT littermates (Fig. 7F). Taken together, these data indicate that $\mathrm{P} 10 \mathrm{LGI}^{-1-}$ mice display a reduction in the number and length of mushroom-type dendritic spines.

To determine whether the changes in spine morphology correlate with alterations in synaptic activity, we mea-

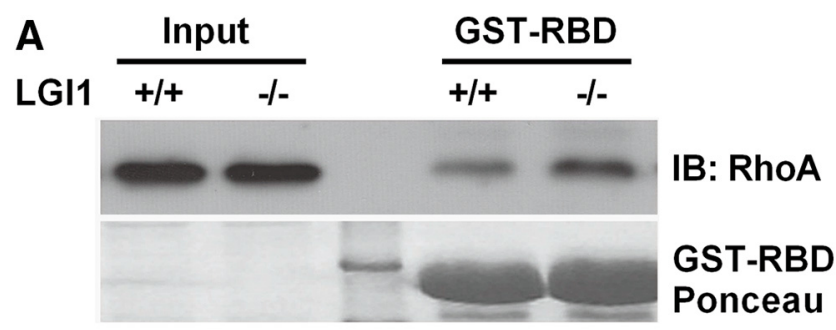

B

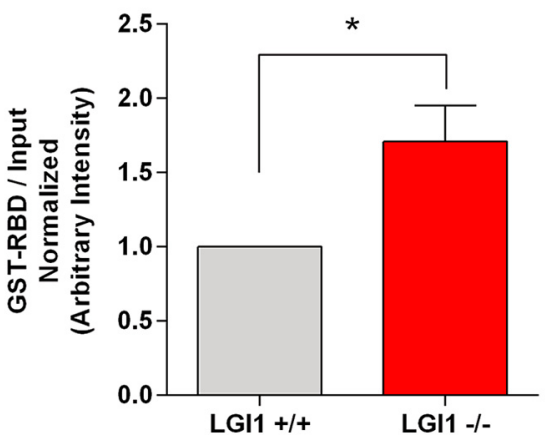

Figure 5. LGI1 normally suppresses RhoA activity in cultured cortical neurons. A total of 15 DIV cortical neurons from $\mathrm{LGI} 1^{-1-}$ mice have increased RhoA activation compared to WT cultures. $\boldsymbol{A}$, Western blottings of input RhoA and active RhoA bound to GST-rhotekin beads (GST-RBD) that bind to GTP-RhoA. The lower panel corresponds to the membrane labeled with Ponceau showing total GST protein. B, Quantification of active GTP-RhoA relative to total RhoA input levels and normalized WT values for each of four experiments. Active GTP-RhoA is significantly higher in lysates from $\mathrm{LGl}^{-/-}$cortical neurons compared to LGl ${ }^{+/+}$controls, $71 \%$ higher, $p=0.0257$, analyzed by unpaired $t$ test; $N=4$ separate experiments. sured mEPSCs in P10 hippocampal CA1 neurons in acute slices derived from $\mathrm{LGl}^{-/-}$and WT littermates. Resting membrane potential input resistance and input-output curves did not differ between LGI1 ${ }^{-/-}$and their WT littermates. However, $\mathrm{LGl}^{-/-}$mice displayed a significant increase in mEPSC interevent interval compared to WT littermate controls (Fig. 8A,B). Taken together with the morphologic data above, this finding suggests that $\mathrm{P} 10$ $\mathrm{LGI}^{-/-}$mice may have weaker synapses that their WT controls. Consistent with this, we found that mEPSC amplitude was modestly but significantly decreased in the CA1 region of $\mathrm{LGl}^{-/-}$null mice $(14.01 \pm 0.18 \mathrm{pA}$ in WT vs $13.12 \pm 0.33 \mathrm{pA}$ in $\mathrm{LGl}^{-1-}$; Fig. $8 \mathrm{C}$ ).

To test whether the changes in $\mathrm{LGI}^{-1 /}$ mice reflected a deficit in presynaptic transmission, we assessed pairedpulse facilitation of CA3 to CA1 synapses. When the lag between first and second paired stimuli ranged from 20 to $500 \mathrm{~ms}$, the ratio of the evoked amplitude did not differ between $\mathrm{LGI}^{-1 /}$ versus WT, indicating that at least by this measure, presynaptic transmission is normal in $\mathrm{LGl}^{-1-}$ mice (Fig. $8 D$ ). Intriguingly, although $\mathrm{P} 10$ mice do not undergo frank seizures, we observed that $\mathrm{LGl} 1^{-/-}$neurons consistently displayed a large increase in event frequency after the first paired stimulus, suggesting that this activity evokes an epileptiform-like discharge (Fig. 8E,F). Taken together, the morphologic and electrophysiological results indicate that $\mathrm{P} 10 \mathrm{LGI}^{1 /-}$ animals have weaker synapses than their WT counterparts and that they exist in a pre-epileptic state in which spontaneous activity is reduced but evoked activity is readily induced.

\section{Discussion}

In the present study, we provide the first evidence that LGl1 directly promotes synapse formation.

Previous result showing that NgR1 activity suppresses synapse formation (Wills et al., 2012; Akbik et al., 2013) and that LGI1 antagonize NgR1 activity (Thomas et al., 2010) prompted the hypothesis that LGI1 facilitates synapse formation. We observed that the addition of exogenous LGI1 to primary cultures of hippocampal neurons induced a $75 \%$ increase in synapse number. The striking result led us to investigate if hippocampal neurons from LGI1 null mice showed defects in synapse formation. We found a highly significant decrease in synapse number in neuronal cultures from $\mathrm{LGl}^{-1-}$ mice compared to WT control cultures. Observing that exogenous acute application of LGI1 increases synapse formation and knockout 
A
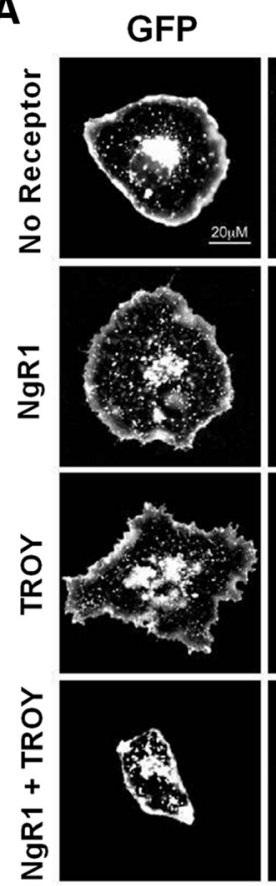

LGI1
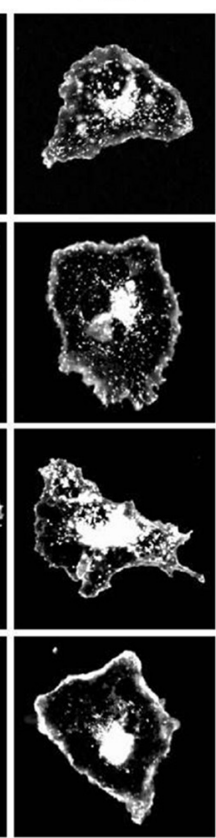

B

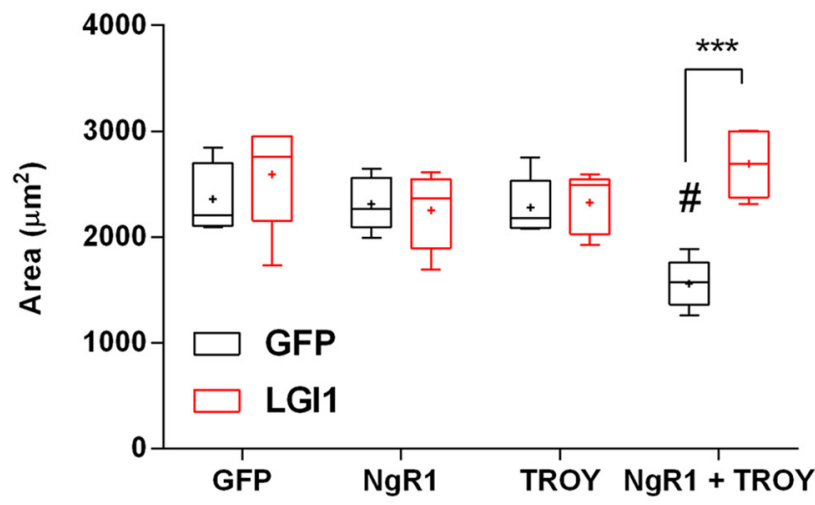

Figure 6. LGI1 regulates a NgR1-TROY receptor complex. $\boldsymbol{A}$, Sample images of COS7 cells transfected with control GFP only; NgR1; TROY; NgR1 + TROY: LGl1; NgR1 + LGl1; TROY + LGl1; NgR1 + TROY + LGl1, together labeled with rhodamine-WGA. COS7 cells transfected with the indicated plasmids and seeded at low density on glass coverslips. In all conditions GFP was cotransfected to follow the expression of the other proteins. Cell membranes were labeled with rhodamine-tagged WGA to visualize cells and measure cell area. B, Area of the cells was quantified using ImageJ Analyze Particles tools. The graph indicates the effect of expression of no receptors (GFP control), each receptor alone, or with LGl1 (indicated in red). Expression of LGI1, NgR1, or TROY separately in COS7 cells has no effect on cell size compared to GFP alone. However, NgR1 and TROY expression together decrease cell size compared to GFP expression alone, $p<0.05$ indicated by \# on the graph. Coexpression of LGl1 together with NgR1 and TROY rescues cell size. This condition is not significantly different from GFP alone. Analysis by two-way ANOVA followed by Bonferroni post hoc tests, $* * * p<0.001 ; n=5$ where each $\mathrm{n}$ is the average area in one separate experiment. For each experiment the areas of $50-100$ cells were quantified.

of LGl1 reduces synapse formation in vivo has led us to conclude that LGI1 is a physiologic regulator of synapse formation.

We previously found LGl1 antagonizes NgR1 signaling in the context of neurite outgrowth on myelin and thus predicted that LGl1 would also act antagonistically to $\mathrm{NgR} 1$ in the context of synapse formation. to investigate the relationship between LGl1 and NgR1 in synapse formation, we quantified synapses in cultures of hippocampal neurons from $\mathrm{NgR}^{-/-}$mice. In line with our results on LGI1 $1^{-/-}$neurons, and consistent with the findings of Wills et al. (2012), we found that $\mathrm{NgR}^{-/-}$hippocampal neurons have $\sim 50 \%$ more synapses than their WT counterparts. We propose the increase in synapse number seen after addition of exogenous LGI1 represents at least in part the antagonism of the $\mathrm{NgR} 1$ mediate synapse repression or elimination. It is conceivable that LGl1 may also be promoting synapse formation directly through another pathway, possibly by stabilizing synapses via ADAM22/23 (Lovero et al., 2015) or regulating potassium channel subcellular localization (Boillot et al., 2016). However, we found that the protein expression level of ADAM22 in COS7 cells is below the immunoblot detection limit (data not shown) suggesting that the role of LGl1 is independent of ADAM22 in this context. Nevertheless, the contri- butions and interactions between different LGI1 signaling pathways remains an interesting avenue for future studies. Primary cultures of hippocampal neurons develop synapses after several days of culture, generally around 12-14 DIV. To further describe of the role of NgR1 and LGI1 in our cultures of hippocampal neurons, we followed the expression of synaptic markers, as well as $\mathrm{NgR} 1$ and LGI1, at various time points after seeding the neurons. We tested the hypothesis that the expression of LGl1 and NgR1 follow the expression profile of the synaptic markers PSD95 and Syn1. Indeed, we observe that the expression of LGI1 and NgR1 increased concurrently with the appearance of synaptic markers in the axonal/dendritic compartment of hippocampal neurons grown on filters. We then asked if $\mathrm{LGI}^{-1-}$ and $\mathrm{NgR}^{-/-}$neurons show a different pattern of expression of synaptic markers than control WT neurons. In agreement with our data on synapse formation describe above, we found that the levels of synaptic markers are decreased in the absence of LGl1 and increased in the absence of NgR1. Thus, our in vitro analyses have revealed that $\mathrm{NgR} 1$ preventing synapses formation whereas LGI1 promotes synapses formation.

We then sought to find a mechanism by which LGI1 can promote synapse formation. It is well described that RhoA regulates synaptogenesis by controlling the actin cyto- 
A

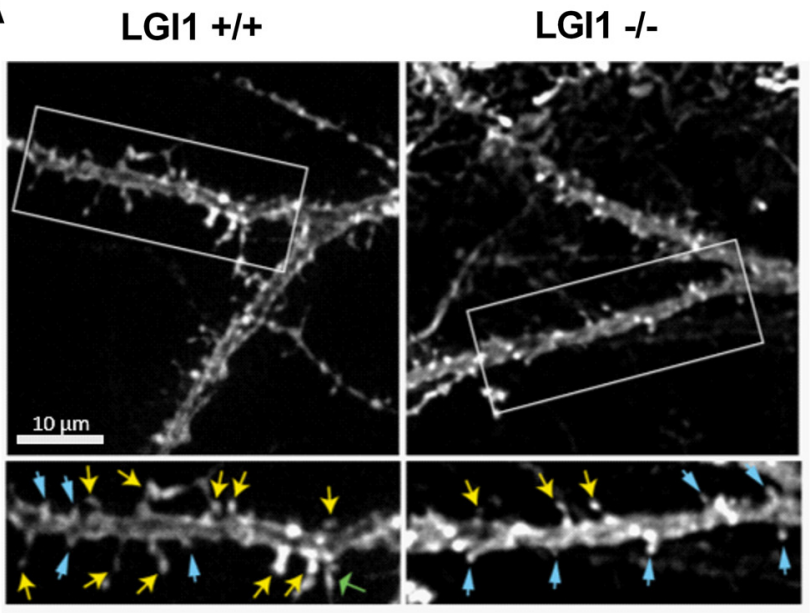

D

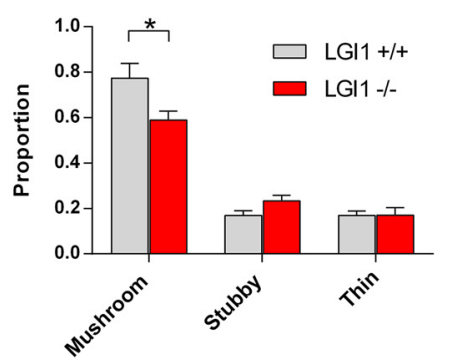

E

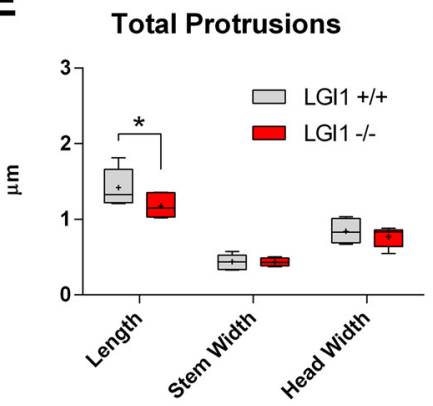

B
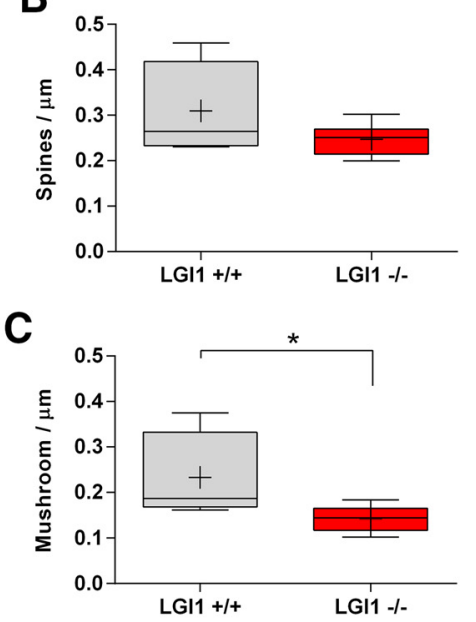

F

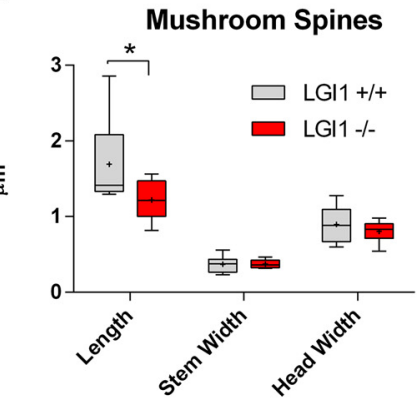

Figure 7. Dendritic spine density and morphology is regulated by LGl1 in vivo. $\boldsymbol{A}$, Sample images of dendritic spines labeled with Dil from acute hippocampal slices from P10 $\mathrm{LGI}^{+/+}$(left) and LGI1/- (right) mice. Segments were taken from the primary bifurcation point from CA1 pyramidal neurons shown in the upper images. The selected region if dendrite is shown below with arrows indicating mushroom spines (yellow), stubby spines (blue, thin arrowheads), and thin spines (green, wide arrowheads). Images were manually traced using the measure tool in ImageJ. B, Quantification of total spine-like protrusion density in spines per $\mu \mathrm{m}$ of dendrite. There is a non-significant trend toward fewer spine-link protrusions in LGl1 ${ }^{-1-}$ mice and WT controls (unpaired $t$ test, $p=0.17$ ). $\boldsymbol{C}$, Proportion of spines categorized based on ratios of the width of the spine head (Hw) to width of the spine neck (Nw) to the spine length, mushroom spines (Hw:Nw > 1.5), stubby spines (Hw:Nw < 1.5 and L:Nw < 1.5), and thin spines (Hw:Nw $<1.5$ and $L: N w>1.5)$. The proportion of mushroom spines is significantly less in LGl1 $1^{-/-}$slices compared to WT controls $(p=0.03)$, stubby spines trend toward an increase $(p=0.08)$, and the proportion of thin spines is unchanged, analyzed by two-way ANOVA with Bonferroni post hoc tests. $\boldsymbol{D}$, Quantification of mushroom type protrusions per $\mu \mathrm{m}$ of dendrite. The density of mushroom type spines is significantly decreased in $\mathrm{LGI}^{-1-}$ slices compared to WT controls, compared by Student's $t$ test $(* p=0.04)$. $\boldsymbol{E}$, Measurements of spine length, neck width, and head width for total spines, significant differences indicated on the graph $(* p=0.031)$, analyzed by two-way ANOVA with Bonferroni post hoc tests. $\boldsymbol{F}$, Measurements of spine length, neck width, and head width for mushroom type spines, significant differences indicated on the graph $(* p=0.034)$ analyzed by two-way ANOVA with Bonferroni post hoc tests. For spine analysis $n=$ 6 animals for each genotype, littermates from three separate experiments, four to six spine segments per animal were quantified.

skeleton (Duman et al., 2015) and that NgR1 is a potent regulator of RhoA signaling (Yamashita and Tohyama, 2003; Wills et al., 2012). We hypothesized that LGl1 acts to reduce $\mathrm{NgR} 1$-mediated activation of RhoA and predicted that level of RhoA activity will be increased in neurons lacking LGI1. Using a well characterized method to assess RhoA activity, we provide direct evidence that RhoA activity is strongly increased in neurons lacking LGI1. To investigate whether LGI1 actually regulates RhoA activity through the NgR1 receptor, we used a well-validated reconstituted system (Zeinieh et al., 2015), in which receptor and ligand expression can be controlled and cell size contraction acts as an accurate read-out for RhoA activity. This approach showed that NgR1 and TROY coexpression dramatically increased RhoA activity and that coexpression of LGI1 strongly counteracts this effect. Taken together, our data show that LGl1 facilitates synapse formation by antagonizing NgR1-dependent RhoA activity.

To characterize the role of LGl1 in synapse formation in vivo, we investigated the effect of LGl1 deletion in synapse morphology and synaptic activity in brain slices. The total number of spines was not affected but mushroom spine number was significantly reduced in LGl1 null mice. These structural changes are consistent with a recent electron microscopic analysis of the cortical region in a distinct $\mathrm{LGI}^{-/-}$null strain, which reported fewer active asymmetric axospinal synapses in LGl1 null animals (Silva et al., 2015). These authors also observed a decrease in spine number and shorter spines within the motor cortex 
A
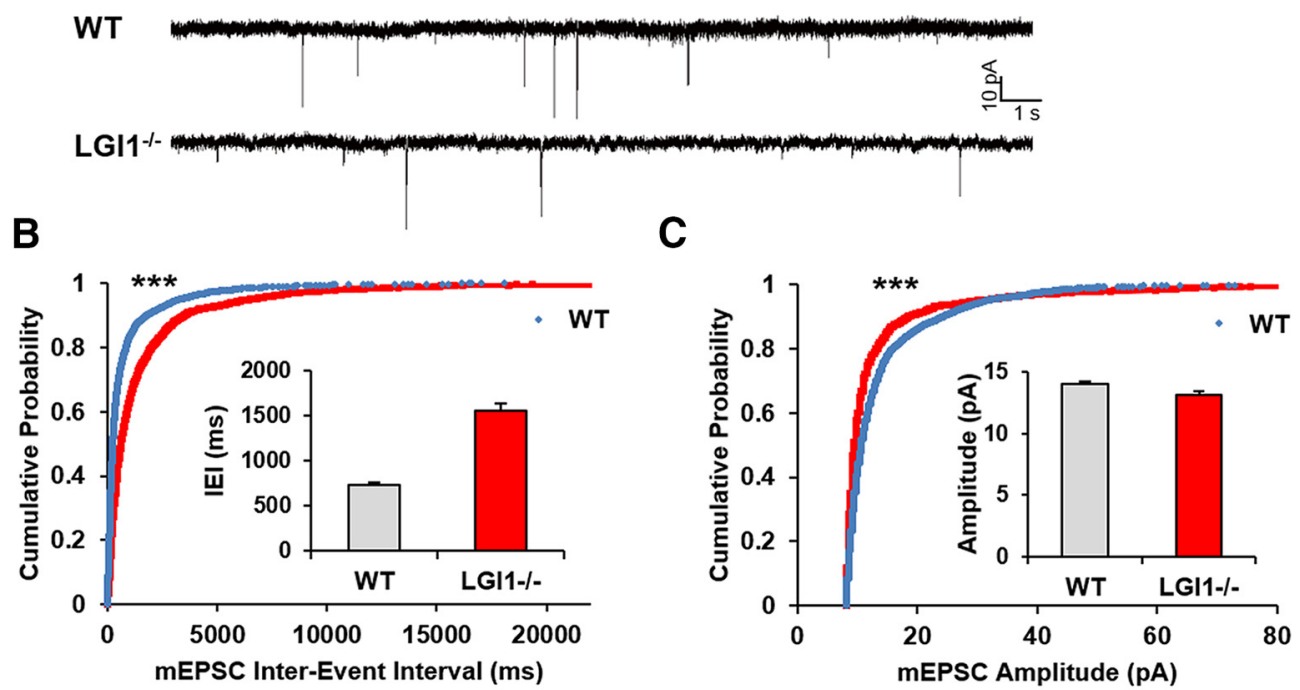

D

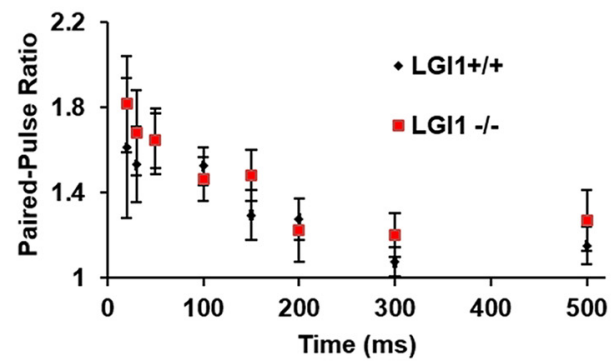

E

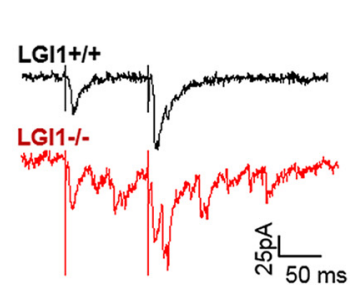

F

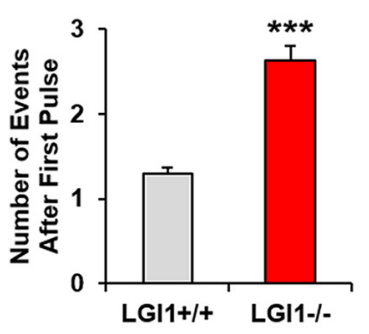

Figure 8. LGl1 deletion alters synaptic activity in the hippocampus. Recordings of mEPSC of CA1 pyramidal neurons in acute hippocampal slices from P10 (A-C) $\mathrm{LGI}{ }^{-/-}$, and $\mathrm{LGl} 1^{+/+}$littermates. $\boldsymbol{A}$, Representative traces of mEPSCs. B, Cumulative probability plot of interevent intervals with inserts showing average values and SE bars. $\boldsymbol{C}$, Cumulative probability graph of mEPSC amplitude, with inserts showing average values and SE bars. Statistical comparisons for mEPSCs were made from cumulative probability data using the Kolmogorov-Smirnov test, $* * * p<0.001 ; n>2000$ events from 7 to 12 cells from three to four separate animals. $\boldsymbol{D}$, Paired-pulse ratio measurement; quantification of the ratio of eEPSC amplitude between the first and second pulse, WT $n=11$ cells, $\mathrm{LGI} 1^{-/-} n=12$ cells. We found no significant differences between pulses, analyzed by $t$ test. $\boldsymbol{E}$, Sample traces of paired-pulse facilitation of CA3-CA1 with 100 ms between pulses. $\boldsymbol{F}$, Quantification of eEPSC in CA1 neurons after the first stimulation of Schaffer collaterals in the CA3 $n=60$ traces for WT and $n=59$ traces for LGI1 ${ }^{-/-}$condition $* * * p<0.0001$ ( $t$ test).

of LGl1 null animals, consistent with our findings in hippocampal neurons.

These morphologic results suggested that LGl1 must be present for synapses to reach maturity, spurring us to examine synaptic transmission in hippocampus lacking LGI1 expression. Whole cell patch clamp recording in CA1 pyramidal neurons showed that mEPSC amplitude is significantly reduced, and mEPSC interevent interval was increased in $\mathrm{LGl} 1^{-/-}$brain slices. The electrophysiological results suggest that synapses in $\mathrm{LGI}^{-/-}$mice are weaker or less abundant in comparison to WT mice. Together, our findings strongly support the hypothesis that LGI1 promotes synapse formation and maturation, in vitro and in vivo.

Interestingly, although we did not observe seizures in mice at the time of the hippocampal preparation $(\mathrm{P} 10)$, we did observe epileptic activity in P10 hippocampal slices from $\mathrm{LGI}^{-/-}$mice after evoked EPSC. We observed this activity using a paired pulse facilitation paradigm whereas an earlier study by Yu et al., detected epileptiform activity in field potentials of $\mathrm{LGI}^{-1-}$ slices exposed to $\mathrm{Mg}^{2+}$-free media (Yu et al., 2010). The mechanisms that account for epileptogenic activity in $\mathrm{LGl}^{-/-}$preparations are not known, but it is notable that basal and evoked IPSCs seem normal in LGI1 null hippocampal slices (Fukata et al., 2010; Yu et al., 2010). It is also interesting that selective deletion of LGI1 from glutamatergic neurons generates spontaneous epileptic behavior in mice, whereas mice lacking GABAergic interneuron expression of LGl1 appear normal (Boillot et al., 2014), indicating that LGl1 expression in excitatory neurons is required to suppress epileptogenic behavior. It is also notable that deletion of LGl1 has shown to decrease the expression of the potassium voltage-gated channel Kv1.1 (Seagar et al., 2017), perhaps facilitating run-away currents in these developing networks. It is conceivable that the decrease in the number of excitatory synapses could produce a homeostatic response that result in a lower of threshold for firing after stimulation, such that stimuli that normally produce a single evoked response result in epileptic activity. 
RhoA is known to play a key role in regulating neuronal morphology during development, synapse formation, spine dynamics, and synaptic plasticity (Luo, 2000; Hering and Sheng, 2001). Growing evidence suggests dysregulation of RhoA signaling contributes to the etiology of multiple psychiatric disorders, including schizophrenia (Hill et al., 2006). Significantly, mutations in NgR1 have been associated with schizophrenia (Budel et al., 2008) and we have recently identified mutations in NgR1 and LGl1 within schizophrenia patients that cause impairments in NgR1-LGl1-RhoA signaling (Thomas et al., 2016). Thus, we believe that understanding the details of LGl1-NgR1-RhoA regulation in different signaling contexts may be important for designing novel therapeutics.

Although many molecules have been identified that promote synapse formation and maturation, fewer molecules are known to regulate synapse removal and turnover. Here we provide support for the hypothesis that a coregulatory loop involving NgR1 and LGl1 is an important regulator of synaptic structure within excitatory neurons of the hippocampus. The correlation of LGl1 and $\mathrm{NgR} 1$ levels with synapse numbers shown in this study suggests that LGl1 normally plays a critical role in regulating synaptic stability and elimination.

\section{References}

Akbik FV, Bhagat SM, Patel PR, Cafferty WB, Strittmatter SM (2013) Anatomical plasticity of adult brain is titrated by Nogo receptor 1 . Neuron 77:859-866. CrossRef Medline

Barrette B, Vallières N, Dubé M, Lacroix S (2007) Expression profile of receptors for myelin-associated inhibitors of axonal regeneration in the intact and injured mouse central nervous system. Mol Cell Neurosci 34:519-538. CrossRef Medline

Boillot M, Huneau C, Marsan E, Lehongre K, Navarro V, Ishida S, Dufresnois B, Ozkaynak E, Garrigue J, Miles R, Martin B, Leguern E, Anderson MP, Baulac S (2014) Glutamatergic neuron-targeted loss of LGI1 epilepsy gene results in seizures. Brain 137:29842996. CrossRef Medline

Boillot M, Lee CY, Allene C, Leguern E, Baulac S, Rouach N (2016) LGI1 acts presynaptically to regulate excitatory synaptic transmission during early postnatal development. Sci Rep 6:21769. CrossRef Medline

Budel S, Padukkavidana T, Liu BP, Feng Z, Hu F, Johnson S, Lauren J, Park JH, McGee AW, Liao J, Stillman A, Kim JE, Yang BZ, Sodi S, Gelernter J, Zhao H, Hisama F, Arnsten AF, Strittmatter SM (2008) Genetic variants of Nogo-66 receptor with possible association to schizophrenia block myelin inhibition of axon growth. J Neurosci 28:13161-13172. CrossRef Medline

Chabrol E, Navarro V, Provenzano G, Cohen I, Dinocourt C, RivaudPéchoux S, Fricker D, Baulac M, Miles R, Leguern E, Baulac S (2010) Electroclinical characterization of epileptic seizures in leucine-rich, glioma-inactivated 1-deficient mice. Brain 133:27492762. CrossRef Medline

Craig AM, Graf ER, Linhoff MW (2006) How to build a central synapse: clues from cell culture. Trends Neurosci 29:8-20. CrossRef Medline

Duman JG, Mulherkar S, Tu YK, X Cheng J, Tolias KF (2015) Mechanisms for spatiotemporal regulation of Rho-GTPase signaling at synapses. Neurosci Lett 601:4-10. CrossRef Medline

Etienne-Manneville S, Hall A (2002) Rho GTPases in cell biology. Nature 420:629-635. CrossRef Medline

Fournier AE, GrandPre T, Strittmatter SM (2001) Identification of a receptor mediating Nogo-66 inhibition of axonal regeneration. Nature 409:341-346. CrossRef Medline
Fukata $\mathrm{Y}$, Adesnik H, Iwanaga T, Bredt DS, Nicoll RA, Fukata M (2006) Epilepsy-related ligand/receptor complex LGl1 and ADAM22 regulate synaptic transmission. Science 313:1792-1795. CrossRef Medline

Fukata Y, Lovero KL, Iwanaga T, Watanabe A, Yokoi N, Tabuchi K, Shigemoto R, Nicoll RA, Fukata M (2010) Disruption of LGl1-linked synaptic complex causes abnormal synaptic transmission and epilepsy. Proc Natl Acad Sci USA 107:3799-3804. CrossRef Medline

Gan WB, Grutzendler J, Wong WT, Wong RO, Lichtman JW (2000) Multicolor "DiOlistic" labeling of the nervous system using lipophilic dye combinations. Neuron 27:219-225. Medline

Gerrow K, El-Husseini A (2006) Cell adhesion molecules at the synapse. Front Biosci 11:2400-2419. Medline

Head K, Gong S, Joseph S, Wang C, Burkhardt T, Rossi MR, LaDuca J, Matsui S, Vaughan M, Hicks DG, Heintz N, Cowell JK (2007) Defining the expression pattern of the LGl1 gene in BAC transgenic mice. Mamm Genome 18:328-337. CrossRef Medline

Hering $\mathrm{H}$, Sheng M (2001) Dendritic spines: structure, dynamics and regulation. Nat Rev Neurosci 2:880-888. CrossRef Medline

Herranz-Pérez V, Olucha-Bordonau FE, Morante-Redolat JM, PérezTur J (2010) Regional distribution of the leucine-rich glioma inactivated (LGl) gene family transcripts in the adult mouse brain. Brain Res 1307:177-194. CrossRef Medline

Hill JJ, Hashimoto T, Lewis DA (2006) Molecular mechanisms contributing to dendritic spine alterations in the prefrontal cortex of subjects with schizophrenia. Mol Psychiatry 11:557-566. CrossRef Medline

Irani SR, Alexander S, Waters P, Kleopa KA, Pettingill P, Zuliani L, Peles E, Buckley C, Lang B, Vincent A (2010) Antibodies to Kv1 potassium channel-complex proteins leucine-rich, glioma inactivated 1 protein and contactin-associated protein-2 in limbic encephalitis, Morvan's syndrome and acquired neuromyotonia. Brain 133:2734-2748. CrossRef

Kaech S, Banker G (2006) Culturing hippocampal neurons. Nat Protoc 1:2406-2415. CrossRef Medline

Kaibuchi K, Kuroda S, Amano M (1999) Regulation of the cytoskeleton and cell adhesion by the Rho family GTPases in mammalian cells. Annu Rev Biochem 68:459-486. CrossRef Medline

Kalachikov S, Evgrafov O, Ross B, Winawer M, Barker-Cummings C, Martinelli Boneschi F, Choi C, Morozov P, Das K, Teplitskaya E, Yu A, Cayanis E, Penchaszadeh G, Kottmann AH, Pedley TA, Hauser WA, Ottman R, Gilliam TC (2002) Mutations in LGl1 cause autosomal-dominant partial epilepsy with auditory features. Nat Genet 30:335-341. CrossRef Medline

Kano M, Hashimoto K (2009) Synapse elimination in the central nervous system. Curr Opin Neurobiol 19:154-161. CrossRef Medline

Karlén A, Karlsson TE, Mattsson A, Lundströmer K, Codeluppi S, Pham TM, Bäckman CM, Ogren SO, Aberg E, Hoffman AF, Sherling MA, Lupica CR, Hoffer BJ, Spenger C, Josephson A, Brené S, Olson $L$ (2009) Nogo receptor 1 regulates formation of lasting memories. Proc Natl Acad Sci USA 106:20476-20481. CrossRef Medline

Lai M, Huijbers MG, Lancaster E, Graus F, Bataller L, Balice-Gordon R, Cowell JK, Dalmau J (2010) Investigation of LGI1 as the antigen in limbic encephalitis previously attributed to potassium channels: a case series. Lancet Neurol 9:776-785. CrossRef Medline

Lee H, Raiker SJ, Venkatesh K, Geary R, Robak LA, Zhang Y, Yeh $\mathrm{HH}$, Shrager P, Giger RJ (2008) Synaptic function for the Nogo-66 receptor NgR1: regulation of dendritic spine morphology and activity-dependent synaptic strength. J Neurosci 28:2753-2765. CrossRef Medline

Lovero KL, Fukata Y, Granger AJ, Fukata M, Nicoll RA (2015) The LGI1-ADAM22 protein complex directs synapse maturation through regulation of PSD-95 function. Proc Natl Acad Sci USA 112:E4129-E4137. CrossRef Medline

Luo L (2000) Rho GTPases in neuronal morphogenesis. Nat Rev Neurosci 1:173-180. CrossRef Medline 
McGee AW, Yang Y, Fischer QS, Daw NW, Strittmatter SM (2005) Experience-driven plasticity of visual cortex limited by myelin and Nogo receptor. Science 309:2222-2226. CrossRef Medline

Morante-Redolat JM, Gorostidi-Pagola A, Piquer-Sirerol S, Sáenz A, Poza JJ, Galán J, Gesk S, Sarafidou T, Mautner VF, Binelli S, Staub E, Hinzmann B, French L, Prud'homme JF, Passarelli D, Scannapieco P, Tassinari CA, Avanzini G, Martí-Massó JF, Kluwe $\mathrm{L}$, et al. (2002) Mutations in the LGl1/epitempin gene on 10q24 cause autosomal dominant lateral temporal epilepsy. Hum Mol Genet 11:1119-1128. Medline

Ohkawa T, Fukata Y, Yamasaki M, Miyazaki T, Yokoi N, Takashima H, Watanabe M, Watanabe O, Fukata M (2013) Autoantibodies to epilepsy-related LGl1 in limbic encephalitis neutralize LGl1ADAM22 interaction and reduce synaptic AMPA receptors. J Neurosci 33:18161-18174. CrossRef Medline

Park JB, Yiu G, Kaneko S, Wang J, Chang J, He XL, Garcia KC, He Z (2005) A TNF receptor family member, TROY, is a coreceptor with Nogo receptor in mediating the inhibitory activity of myelin inhibitors. Neuron 45:345-351. CrossRef Medline

Ren XD, Kiosses WB, Schwartz MA (1999) Regulation of the small GTP-binding protein Rho by cell adhesion and the cytoskeleton. EMBO j 18:578-585. CrossRef Medline

Sagane K, Ishihama Y, Sugimoto H (2008) LGI1 and LGI4 bind to ADAM22, ADAM23 and ADAM11. Int J Biol Sci 4:387-396. Medline

Seagar M, Russier M, Caillard O, Maulet Y, Fronzaroli-Molinieres L, De San Feliciano M, Boumedine-Guignon N, Rodriguez L, Zbili M, Usseglio F, Formisano-Tréziny C, Youssouf F, Sangiardi M, Boillot M, Baulac S, Benitez MJ, Garrido JJ, Debanne D, El Far O (2017) LGI1 tunes intrinsic excitability by regulating the density of axonal Kv1 channels. Proc Natl Acad Sci USA 114:7719-7724. CrossRef Medline

Senechal KR, Thaller C, Noebels JL (2005) ADPEAF mutations reduce levels of secreted LGI1, a putative tumor suppressor protein linked to epilepsy. Hum Mol Genet 14:1613-1620. CrossRef Medline

Shao Z, Browning JL, Lee X, Scott ML, Shulga-Morskaya S, Allaire N, Thill G, Levesque M, Sah D, McCoy JM, Murray B, Jung V, Pepinsky RB, Mi S (2005) TAJ/TROY, an orphan TNF receptor family member, binds Nogo-66 receptor 1 and regulates axonal regeneration. Neuron 45:353-359. CrossRef Medline
Silva J, Sharma S, Cowell JK (2015) Homozygous deletion of the LGl1 gene in mice leads to developmental abnormalities resulting in cortical dysplasia. Brain Pathol 25:587-597. CrossRef Medline Thomas R, Favell K, Morante-Redolat J, Pool M, Kent C, Wright M, Daignault K, Ferraro GB, Montcalm S, Durocher Y, Fournier A, Perez-Tur J, Barker PA (2010) LGI1 is a Nogo receptor 1 ligand that antagonizes myelin-based growth inhibition. J Neurosci 30:66076612. CrossRef Medline

Thomas RA, Ambalavanan A, Rouleau GA, Barker PA (2016) Identification of genetic variants of LGl1 and RTN4R (NgR1) linked to schizophrenia that are defective in NgR1-LGl1 signaling. Mol Genet Genomic Med 4:447-456. CrossRef Medline

Unsain N, Heard KN, Higgins JM, Barker PA (2014) Production and isolation of axons from sensory neurons for biochemical analysis using porous filters. J Vis Exp (89).

Wills ZP, Mandel-Brehm C, Mardinly AR, McCord AE, Giger RJ, Greenberg ME (2012) The nogo receptor family restricts synapse number in the developing hippocampus. Neuron 73:466-481. CrossRef Medline

Wong ST, Henley JR, Kanning KC, Huang KH, Bothwell M, Poo MM (2002) A p75(NTR) and Nogo receptor complex mediates repulsive signaling by myelin-associated glycoprotein. Nat Neurosci 5:1302-1308. CrossRef Medline

Yamashita T, Tohyama M (2003) The p75 receptor acts as a displacement factor that releases Rho from Rho-GDI. Nat Neurosci 6:461-467. CrossRef Medline

Yu YE, Wen L, Silva J, Li Z, Head K, Sossey-Alaoui K, Pao A, Mei L, Cowell JK (2010) Lgi1 null mutant mice exhibit myoclonic seizures and CA1 neuronal hyperexcitability. Hum Mol Genet 19:17021711. CrossRef

Zeinieh M, Salehi A, Rajkumar V, Barker PA (2015) p75NTRdependent Rac1 activation requires receptor cleavage and activation of an NRAGE and NEDD9 signaling cascade. J Cell Sci 128:447-459. CrossRef Medline

Zheng B, Atwal J, Ho C, Case L, He XL, Garcia KC, Steward O, Tessier-Lavigne M (2005) Genetic deletion of the Nogo receptor does not reduce neurite inhibition in vitro or promote corticospinal tract regeneration in vivo. Proc Natl Acad Sci USA 102:1205-1210. CrossRef Medline 